\title{
Hydrochemistry of the Eocene aquifer at the desert fringes of west El-Minya Governorate, Egypt
}

Yahia Gedamy, Yasser Abdulhady and Ehab Zaghlool

Hydrogeochemistry Department, Desert Research Center, El-Matariya, Cairo, Egypt

Received: 20 July 2019/ Accepted 10 Oct. 2019/Publication date: 30 Nov. 2019

\begin{abstract}
The present work focuses on the hydrochemical setting of the Eocene limestone aquifer along the area lying west of El-Minya Governorate. To achieve this goal, seventy-four water samples from the Eocene aquifer, as well as ten water samples from the Pleistocene aquifer as guidance samples were collected. Also, two samples were collected from both El-Ibrahimia and Bahr Yousf canals in the study area. The collected water samples were subjected to chemical analyses to determine both major cations and anions in order to identify the hydrochemical characteristics of the Eocene aquifer in the study area through the discussion of both the salinity of the groundwater, hydrochemical coefficients, hydrochemical facies, hypothetical salts combinations, geochemical classification, geochemical modeling and statistical analyses as well as evaluation of the groundwater for different purposes. The obtained results revealed that; majority of the Eocene groundwater samples in the study area $(81 \%)$ lie in the fresh zone and $17 \%$ of the total groundwater samples lie in the brackish zone while the saline water is less pronounced. The ionic ratios indicated that, the groundwater samples have a mixed mineralization that is possibly pure marine water affected by leaching, dissolution and cation exchange processes of both meteoric water and terrestrial salts. The hydrochemical facies and assemblages of hypothetical salts combinations indicated that; the groundwater of this aquifer is, chemically, goes through three stages of development; less chemically developed stage at the southern portion of the study area, intermediate state of development at the central portion of the study area and finally more chemically evoluted stage at the northern portion of the study area. Both the assemblages of hypothetical salts combinations and Piper's trilinear diagram as well as the statistical analyses confirmed that the Eocene aquifer is hydraulically connected with the overlain Pleistocene aquifer through the faults plain. Also, the irrigation canals and the return flow after irrigation as well as the seepage from the upper aquifer (Pleistocene aquifer) are the main sources of recharging for the Eocene aquifer. Most of the Eocene groundwater samples are under-saturated with calcite, while all groundwater samples of the Eocene aquifer are under-saturated with respect to the aragonite, gypsum, anhydrite and halite. Most of the Eocene groundwater samples in the study area are suitable for drinking and irrigation purposes. Finally, some recommendations are given.
\end{abstract}

Keywords: Hydrochemistry, Groundwater, Eocene aquifer, West El-Minya, Egypt

\section{Introduction}

The Egyptian government makes attention to develop the desert hinterland of Upper Egypt governorates in order to increase the agricultural land and create jobs for young people and decrease their migration to Cairo as well as the prosperity of the Egyptian economy. This is achieved by reclamation of more desert lands which needs more water resources.

Egypt is located in the arid zone of North Africa, where the fresh water resources are limited due to the fixed share from the Nile and groundwater systems. Growing population, agricultural expansion, and urbanization have placed a heavy demand on water resources (Ahmed and Ali, 2009). So, groundwater is considered one of the most important sources of water for most uses. Also, the groundwater sources in the study area have great advantages due to the low cost of production and their high quality.

The development of desert areas by building up new communities attracted the attention of the decision makers and the inventors. This natural expansion of agricultural, industrial and civil activities in the desert areas needs more exploration activities for groundwater resources. The desert area of 
west El-Minya is considered the most desert areas subjected to reclamation in the past twenty years, depending mainly on the groundwater extraction through drilled wells (Abdel Moneim et al., 2016).

West El-Minya area is considered one of the promising areas for future development plans in Egypt. The continued water deficiency in Egypt and the probabilities for supplemental deficits in River Nile water, especially after the Nile Basin countries beginning in constructing new dams; directing the efforts of the Egyptian government to find solutions to this problem by identifying additional new water resources (Yousif et al., 2018).

El-Minya Governorate area is characterized by arid to semi-arid climate, hot, dry, and rainless in summer, and mild with rare precipitation in winter. The temperature varies from $4.6^{\circ} \mathrm{C}$ in January to $20.5^{\circ} \mathrm{C}$ in July and $20.4^{\circ} \mathrm{C}$ in January to $37.1^{\circ} \mathrm{C}$ in June, respectively. The rainfall attains $1.74 \mathrm{~mm} /$ month in March and rare in June, August and September, with an average value of $0.87 \mathrm{~mm} /$ month (Elewa et al., 2013), where the amount of rainfall is annually about $19.6 \mathrm{~mm} /$ year (Salem, 2015). The maximum rainfall in one day of rain and heavy storms is $7.6 \mathrm{~mm} /$ day in October (Yousif et al., 2018). Therefore, the contribution of rainfall to groundwater recharge is expected to be scarce.

Evaporation in El-Minya Governorate ranges from $14.85 \mathrm{~mm} / \mathrm{month}$ in June to $3.54 \mathrm{~mm} / \mathrm{month}$ in December, with the average value of $8.92 \mathrm{~mm} / \mathrm{month}$, and total amount of about $107.04 \mathrm{~mm} /$ year. Evapotranspiration at El-Minya is $4897.91 \mathrm{~mm} /$ year (Korany, 1980 and Korany et al., 2006). The mean monthly relative humidity during daytime according to Egyptian Meteorological Authority data ranges from $39.2 \%$ in May to $68.8 \%$ in December, with an average value of $54.76 \%$ (Elewa et al., 2013).

Some studies were carried out on the Eocene limestone aquifer at the desert fringe of west ElMinya Governorate by some authors, among them; El-Kashouty (2010), El-Kashouty et al. (2012), Ibrahim (2013), ElDeeb et al. (2015), Salem (2015), Abdel Moneim et al. (2016), Ibrahim and Lyons (2017) and Yousif et al. (2018).

The current study focuses on; (1) The hydrochemical characteristics of the Eocene aquifer at the desert fringes of west El-Minya Governorate area and; (2) Evaluating the groundwater for different purposes.

\section{Study area}

El-Minya Governorate is one of the Upper Egypt Governorates. It is located about halfway between Cairo and Luxor. It lies about $245 \mathrm{~km}$ south Cairo on the western bank of the River Nile and the population of El-Minya Governorate reached 5,630,468 people (Census estimation, 2019). The study area is an elongated strip located to the west of El-Minya Governorate between longitudes $30^{\circ} 25^{\prime}$ and $30^{\circ} 45^{\prime} \mathrm{E}$, and latitudes $27^{\circ} 30^{\prime}$ and $28^{\circ} 45^{\prime} \mathrm{N}$ (Fig.1). It covers about $6717 \mathrm{~km}^{2}$. The area is limited by the old cultivated areas from east, Markaz El-Fashn (Beni Suef Governorate) from the north and Markaz Dairut (Assiut Governorate) from the south.

\section{Geomorphological, geological and hydrogeological setting}

\section{I-Geomorphological aspects}

Geomorphologically, the study area is moderately elevated plateau with respect to River Nile and it is structurally formed, composed of mainly limestone covered with alluvial deposits of sand and gravels (Fig.2). The Eocene rocks constitute the main outcrops, capped by poorly consolidated sand, gravel and clay (Quaternary aquifer), (Abu Heleika and Niesner, 2009). In other words, in the present study three geomorphologic units were recognized, including; the limestone plateau (Tableland), old alluvial plain (River terraces) and recent alluvial plain (Salem, 2015);

\section{I.1-The limestone plateau (tableland)}

The limestone plateau (tableland) covers the western part of the investigated area. It is bounded by a structural scarp. Its surface slopes eastward with elevations range between $+145 \mathrm{~m}$ and $+90 \mathrm{~m}$. It is structurally controlled by step faults due the rift of the Nile basin. The plateau surface is interrupted by some structural isolated hills. The western desert road (Cairo-Assuit) and the sand dune strain across the eastern portion of the limestone plateau in N-S direction; sand dune belt of Western Desert which started from south Qattara Depression and extending to the west of El-Minya (Shabana, 2010 
and Salem, 2015). The surface of the plateau is dissected by some drainage lines which run eastward. To the east of the sand dunes strain, the limestone plateau disappears beneath the old river terraces and recent Nile sediments.

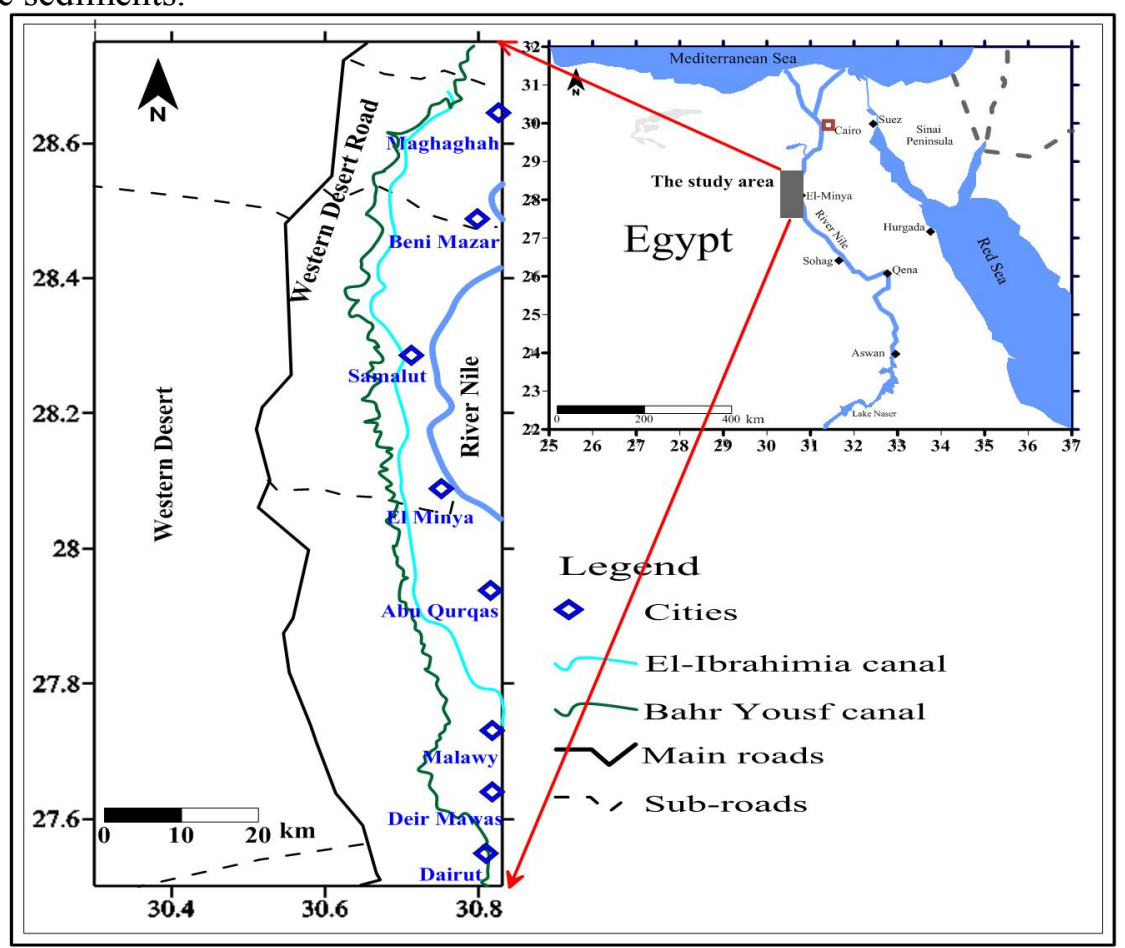

Fig.1: The location map of the study area

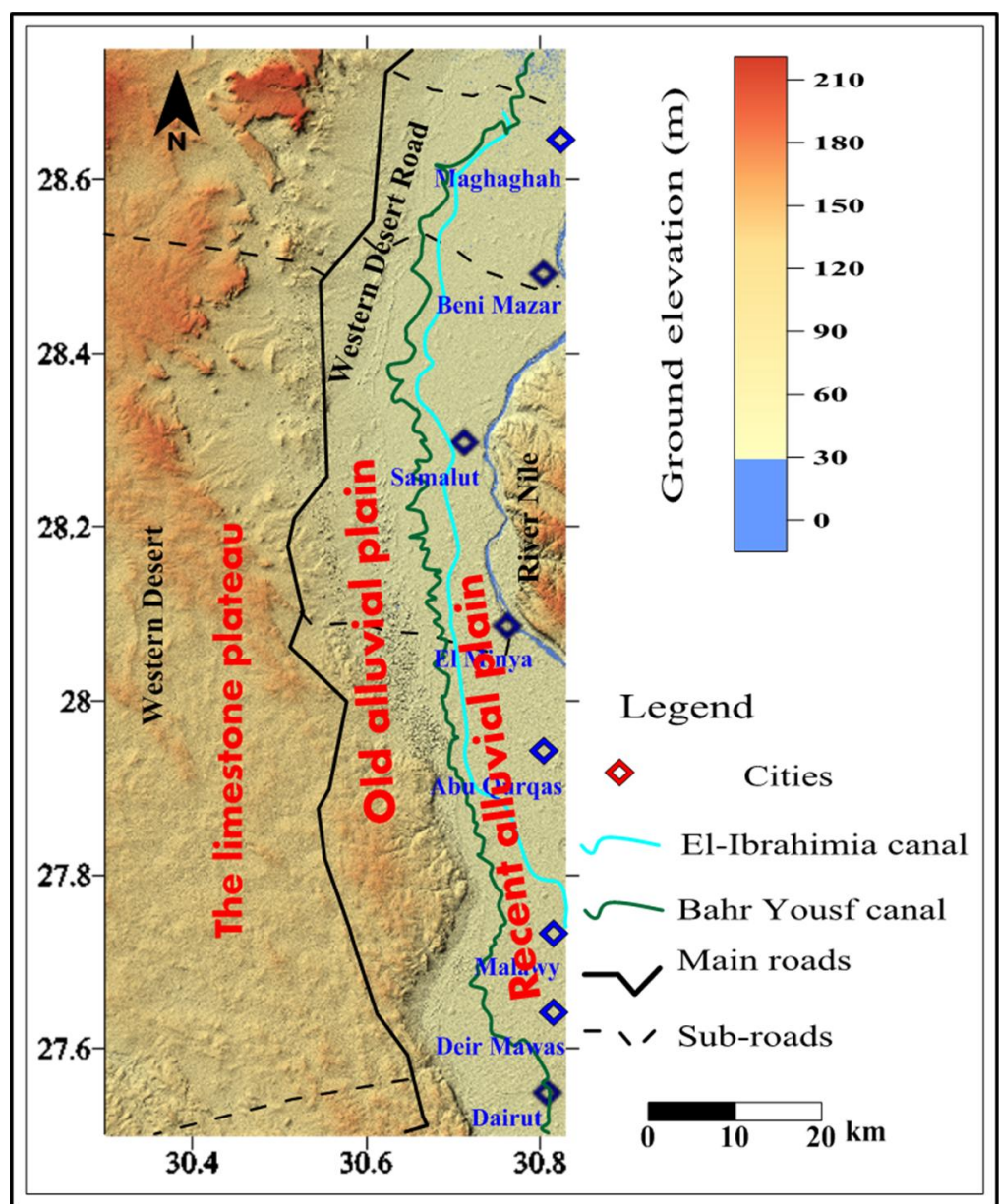

Fig. 2: Geomorphological map of the study area using digital elevation models (DEM) 


\section{I.2-Old alluvial plain (River terraces)}

The Old alluvial plain is a transition zone between the cultivated lands (recent flood plain) and the highlands of the limestone plateau. The elevation of the old alluvial plain ranges between 10 and $25 \mathrm{~m}$ above the recent flood plain. It is also covered by coarse sand and gravel which is quarrying areas.

\section{I.3- Recent alluvial plain}

It occupies the area between the old alluvial plain eastward till the current River Nile channel. Its surface slopes northward with elevations range between +25.5 and $+26.5 \mathrm{~m}$. It is also striated by the main irrigation canals which flow northward (El-Ibrahimia and Bahr Yousf) and their tributaries directions.

\section{II-Geological aspects}

Geology has a main effect on the quality and occurrence of the groundwater. The stratigraphic succession in the study area is essentially represented by sedimentary rocks (Tertiary and Quaternary). The Pleistocene and Eocene sediments at both the eastern and western borders of the River Nile are built up of from base to top as follows (Abu Heleika and Niesner, 2009), (Fig.3).

1- Oligocene-Pleistocene gravel and sand, covers a wide area and composed mainly of gravel, sand and limestone fragments varying in size with dark brown color, its maximum thickness reaches $200 \mathrm{~m}$ in the western portion. It is considered as a good local aquifer in the desert fringes.

2- Massive limestone of El-Minya and Drunka Formations underlie the aquifer system.

3- Limestone with shale and marl intercalation (Wadi Rayan Formation) overlies the aquifer system and concentrated in the northern part of the study area and this limestone has a thickness increase in the northern part.

4- Tertiary volcanic (basaltic) is recorded in some localities in the area. It was detected that the Tertiary volcanic basalt sheets intruded into the chalky limestone aquifer that enhance the interconnections of the, fissures, joints and fracture systems (Abu Heleika and Niesner, 2009). There is a thin clay patch in the aquifer due to the northern part of the study area.

5- Limestone of Samalut and Minya formations (Mokattam limestone group) are represented the investigated aquifers. It is chalky and dense limestone contains fissures, fractures, and joints, which all constructs the conduits of the groundwater system.

6- Disconnected clay bands (Pliocene), completely absent in the western and northern parts of the study area (Abu Heleika and Niesner, 2009). It deposited during the transgression of the Pliocene sea into the old eroded valley of the Eocene limestone plateau (Said, 1997).

7- Unconsolidated sands and gravels (Quaternary aquifer) intercalated with clay lenses. The thickness increases generally eastwards in the direction of Nile Valley. It is partially saturated with groundwater.

Structurally; the Nile valley is bounded by wrench faults that more or less parallel either to the Gulf of Suez or the Gulf of Aqaba directions (Youssef, 1968). They are of normal type trending NWSE. They play a great role in recharging the middle Eocene limestone aquifer (Shabana, 2010). In other words, Yousif et al. (2018) stated that, the existence of the structural delineation of the studied area shows that the area is affected by several trends of structural lineaments (faults and fractures). These faults play a great role in the occurrences of the groundwater aquifers in this area. The main trend of lineaments is NE-SW followed by NW-SE directions. Structural lineaments are concentrated in the proximities of the southwest, southeast and northeast of the study area. The exposures of Eocene rocks are highly fractured by cracks and joints that are mostly connected. 


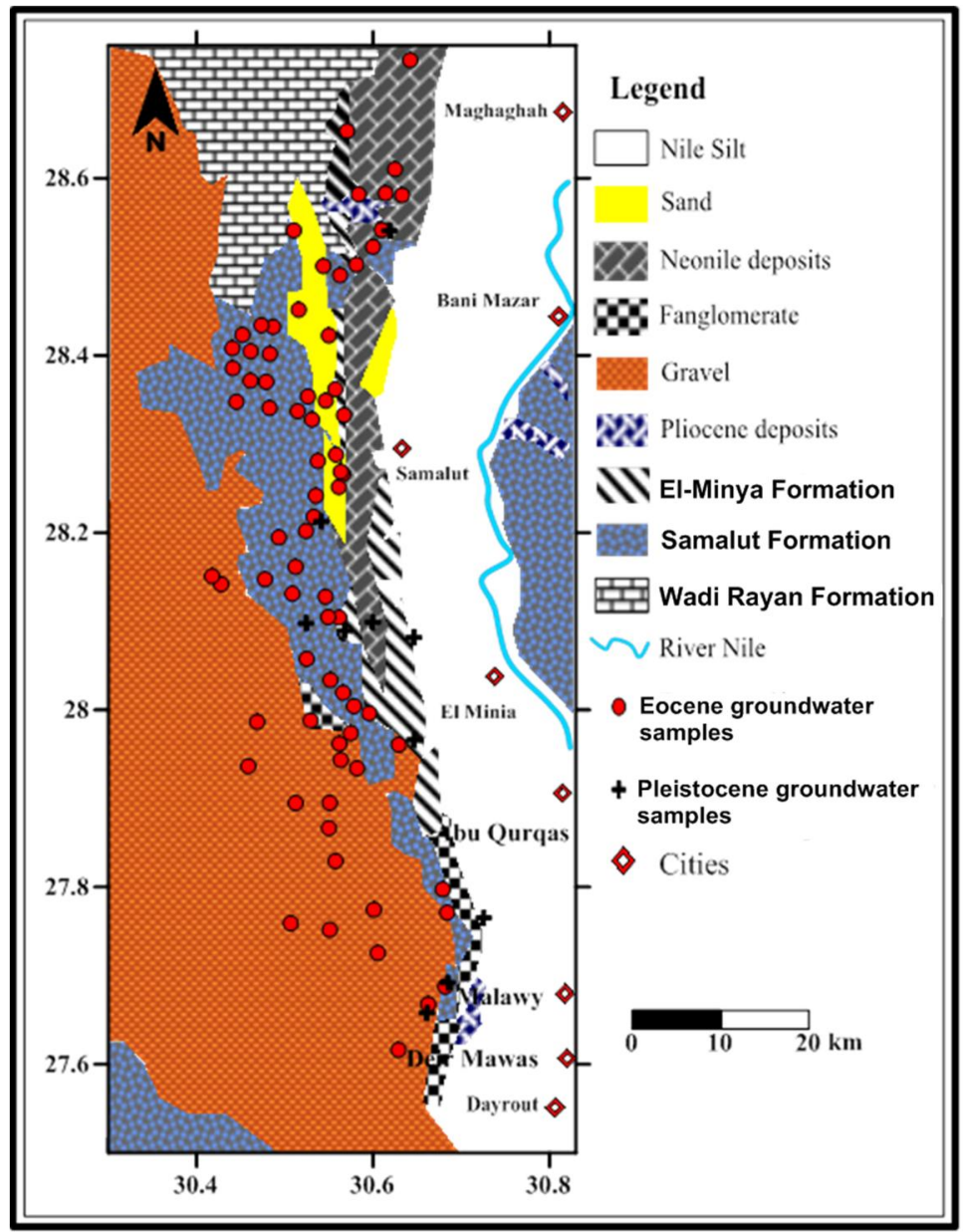

Fig. 3: Geological map of the study area

\section{III-Hydrogeological aspects}

Hydrogeologically, the investigated aquifer in the study area (Eocene limestone aquifer) underlies the Pleistocene aquifer and overlies the Nubian sandstone aquifer (Tantawai, 1992). This aquifer is made up of hard, some white, highly fossiliferous limestone with shale and marl intercalation. The groundwater of the Eocene aquifer occurs under unconfined conditions.

The Eocene limestone aquifer is mainly recharged from surrounding aquifers through fissures, joints and fracture systems, where the possible recharge of the Eocene limestone aquifer in the study area may occur from the following sources;

1. Direct recharge by downward seepage through percolation of the atmospheric precipitation and the occasional flashes.

2. Direct recharge from the percolation of irrigation canal water and from the local seepage of the overlying Pleistocene aquifer, this agreed with El-Kashouty (2010) which stated that the fractured limestone aquifer in the western River Nile between Beni Suef and El-Minya is mainly recharged by the surrounding aquifers and agricultural wastewater.

3. Also, the stable isotope values of Middle Eocene limestone aquifer (Samalut Formation) in the western part reveal a contribution from the paleo-water of the Nubian sandstone aquifer through the upward leakage (Ibrahim and Lyons, 2017).

On the other hand, the discharge of the Eocene aquifer occurs essentially through the pumping wells for irrigation purposes.

In general, there are three directions of the groundwater flow in the study area;

1- The general trend of the groundwater flow from the south to north direction.

2- The groundwater flow from the southeast (west Mallawy locality) to the northwest (west of Mattai and Beni-Mazar localities) direction. 
3- The groundwater flow from west to east direction at the middle of the study area, i.e., the groundwater flows towards the eastern part (due Bahr Yousf and River Nile). The latter is considered as a discharge area rather than a recharge (El-Kashouty, 2010).

The Quaternary and Eocene aquifers are hydraulically interconnected and the former is also recharged mainly from the surface water, particularly through the irrigation canals (Ismail et al., 2015), (Fig.4). Local karstification enhances the infiltration of the return flow after irrigation (agricultural wastewater) into the aquifer system. The pumping rate ranging from 80 to $120 \mathrm{~m}^{3} / \mathrm{h}$ (ElKashouty, 2010), the saturated thickness of the aquifer varies from 10 to $120 \mathrm{~m}$ that increased eastwards, when it becomes deeper and provides a high groundwater yield (El-Kashouty, 2010). Total porosity is $9-34 \%$ (Fitzer et al., 2002).

The infiltrating water from the fields is expected to raise the water table levels, reflected by the groundwater flow towards the River Nile. In carbonate massifs, flow patterns are conditioned by karstification processes which develop a conduit network and preserve low permeability microfractured blocks (Baena et al., 2008). However, the special character of karst aquifers such as rapid infiltration and transport over long distances makes them more vulnerable to contamination than other hydrogeological environments (Ravbar and Goldscheider, 2009). Therefore, karst groundwater requires appropriate and careful managing. The River Nile was a discharged area not a recharge one. So, the negative impact of the groundwater system in both the Quaternary and Eocene limestone aquifers will influence on the River Nile water quality (Tantawy et al., 2006).

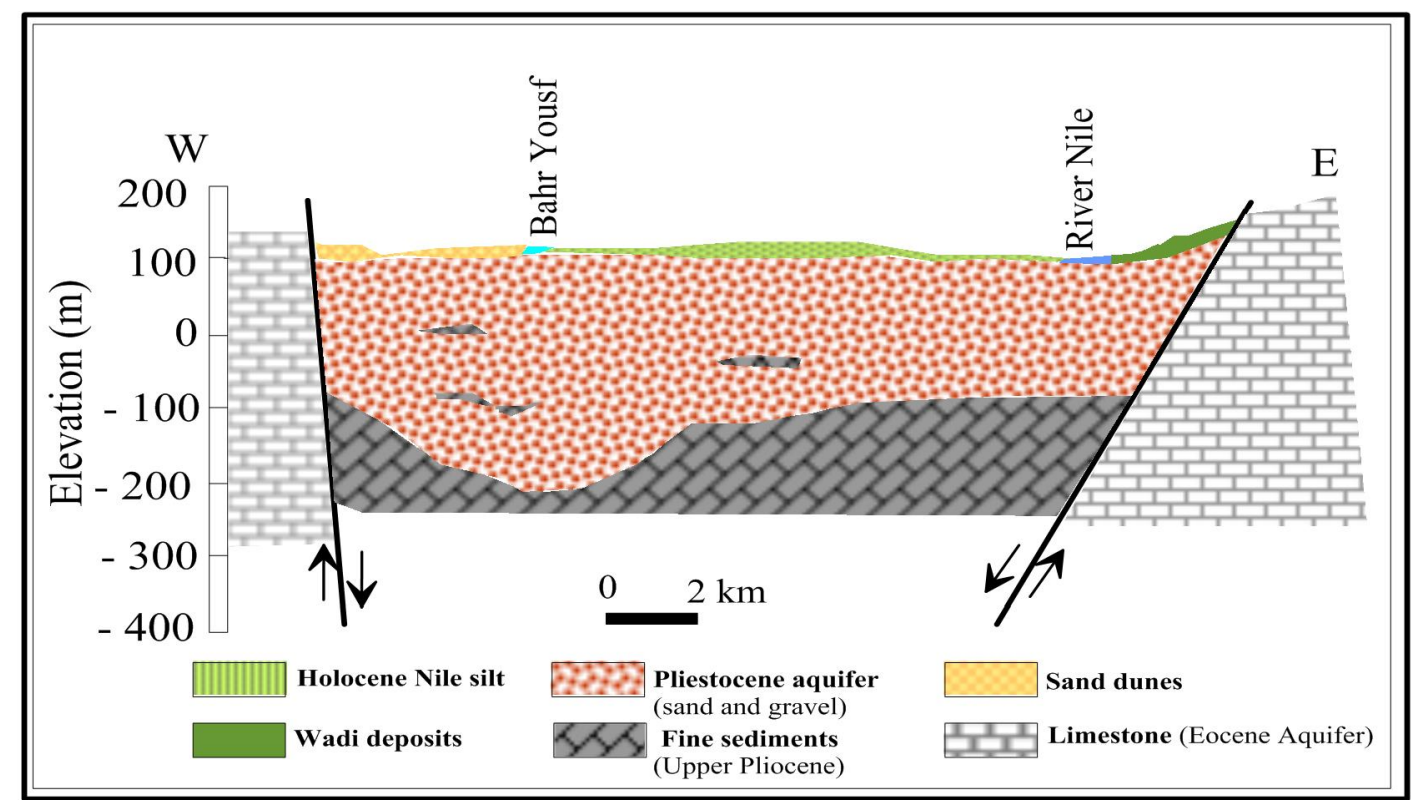

Fig. 4: Cross section across the Nile Valley at El-Minya district (Modified after IWACO and RIGW, 1986)

\section{Materials and Methods}

Eighty-four groundwater samples were collected from the study area at different sites between Maghagha and Deir Mawas cities in west El-Minya Governorate area during the year 2018, representing both the Eocene aquifer (seventy-four water samples) and the Pleistocene aquifer (ten water samples as guidance samples). Also, both El-Ibrahimia and Bahr Yousf canals were represented by one sample for each one of them (Fig.5). The locations of the samples were determined using GPS instruments (model Garmin Etrex). The collected water samples were analyzed in the Desert Research Center laboratories to determine the major cations and anion concentrations according to the methods adopted by Rainwater and Thatcher (1960).

Calcium $\left(\mathrm{Ca}^{2+}\right)$, magnesium $\left(\mathrm{Mg}^{2+}\right)$, carbonate $\left(\mathrm{CO}_{3}{ }^{2-}\right)$, bicarbonate $\left(\mathrm{HCO}_{3}{ }^{-}\right)$and chloride $\left(\mathrm{Cl}^{-}\right)$ were determined by the titration methods while, sulfate $\left(\mathrm{SO}_{4}{ }^{2-}\right)$ was estimated using a UV spectrophotometer Unicam; model UV4-200. Also, Sodium $\left(\mathrm{Na}^{+}\right)$and potassium $\left(\mathrm{K}^{+}\right)$constituents were assessed using a flame photometer model PFP 7, Jenway, (UK). 


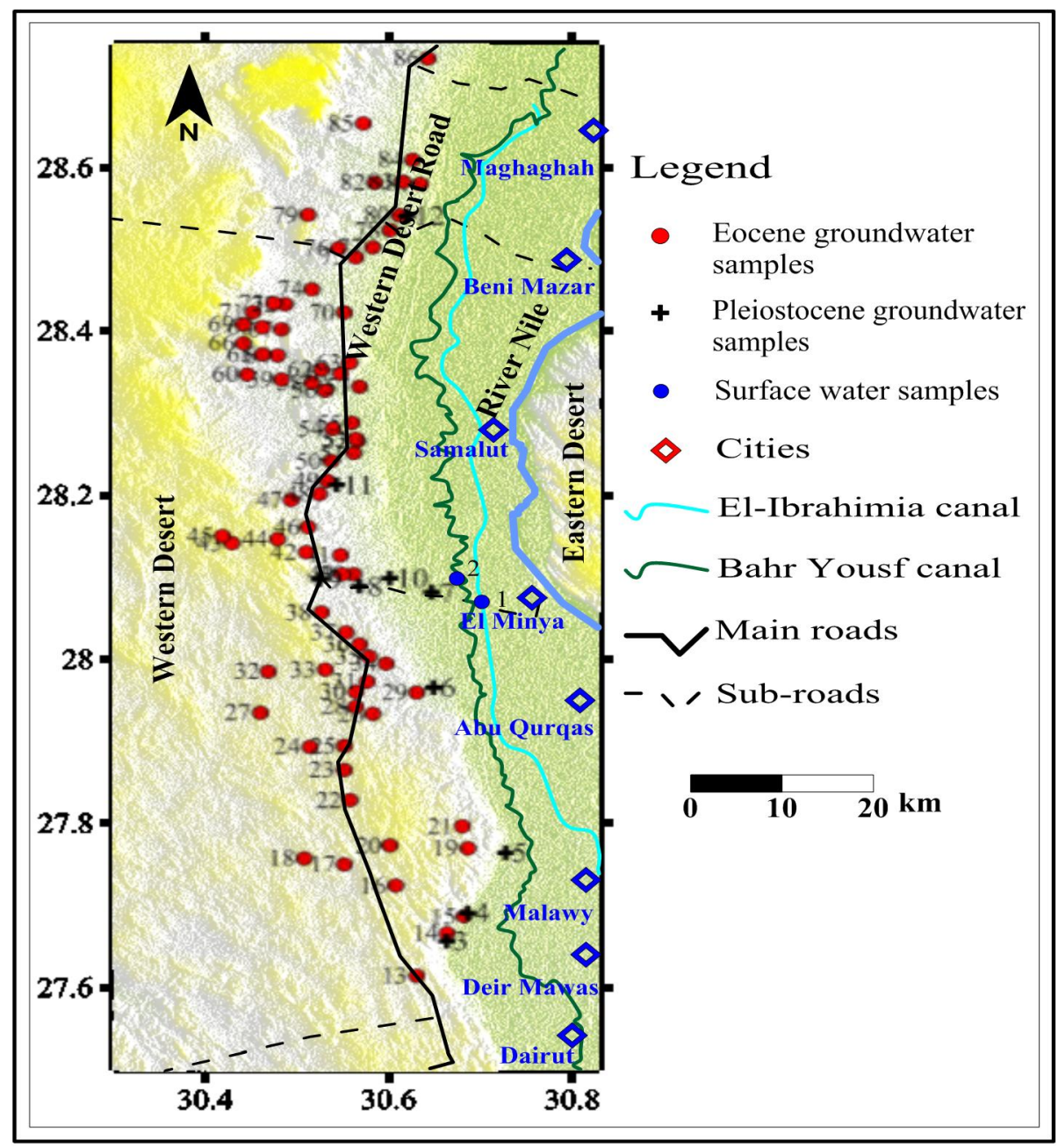

Fig.5: Water samples location map at the study area

\section{Results and Discussion}

To identify the hydrochemical characteristics of the Eocene groundwater in the study area, it must discuss the salinity of the groundwater, hydrochemical coefficients, hydrochemical facies, hypothetical salts combinations, geochemical classification, geochemical modeling and statistical analyses.

\section{Water salinity}

The total dissolved solids could be used to understand the chemical maturity and water flow history of certain aquifer systems. The term salinity refers to the total dissolved concentration of major ions. Different methods are used for water classification corresponding to its salinity values, among them Chebotarev's classification (1955). According to this classification, the natural water is classified into three main categories of total salinity; fresh water (TDS $<1500 \mathrm{mg} / \mathrm{l}$ ), brackish water $(1500$ to $5000 \mathrm{mg} / \mathrm{l})$ and saline water (TDS $>5000 \mathrm{mg} / \mathrm{l})$.

The groundwater salinity of the Eocene aquifer in the study area varies from 294 to $6164 \mathrm{mg} / \mathrm{l}$, with a mean value of $1093 \mathrm{mg} / 1$. According to Chebotarev's classification (1955), majority of the groundwater samples in the study area $(81 \%)$ have a relatively low salinity ranges from 294 to $1393 \mathrm{mg} / 1$ (fresh water) at the southern and central parts of the study area, while $17 \%$ of the total groundwater samples have salinities ranges from 1544 to $4062 \mathrm{mg} / 1$ (brackish water) at the central and northern parts of the study area and the rest of the groundwater samples (2\%) have salinities ranges from 5009 to $6816 \mathrm{mg} / 1$ (saline water) at the northern part of the study area. 
The low salinity values refer to that these wells may be receiving a considerable recharge from El-Ibrahimia and Bahr Yousf canals (Table 1 and Fig.6). This is confirmed by Yousif et al. (2018), who stated that the low salinity values and water table map as well as the obtained stable isotopes data revealed that the Eocene aquifer is recharged from the River Nile where it has the isotopic signature of the modern Nile water with a slight contribution of Paleo-water of the Nubian sandstone.

There are three directions of water salinity increasing in the study area; (1) Water salinity increase from the south to north direction with the general groundwater flow as the land gradient trend, (2) Water salinity increase from the southeast to northwest direction due to the percolation from the irrigation canals (El-Ibrahimia and Bahr Yousf canals) to the concerned aquifer and (3) Water salinity increase from the west to east direction due to the leaching and dissolution processes for the limestone plateau (the transportation of carbonate materials from plateau of limestone by weathering) to the groundwater.

The presence of brackish and saline water of these water points could be attributed to the process of dissolution of carbonate rocks during the subsurface flow of groundwater through cracks and joints or due to the carbonate materials that was transported from plateau of limestone by weathering, as well as the presence of clay layers and marl intercalation in the succession of limestone (intercalation between shale and clay with the limestone layers) at north of the study area. In other words, the higher water salinity at some wells may be due to the partial penetration of these wells by marine clay strata of Pliocene age as at the northern part of the study area. Also, the higher values of water salinity may be attributed to the over-pumping activity through the reclamation projects and the infiltration of return flow after irrigation through the shallow depths to the groundwater as well as high development (Fig.6).

Also, the groundwater salinity is directly affected by the lithologic nature of the water bearing formation. This is manifested by Tihansky and Knochenmus (2001) who stated that the karstic transformation or post-depositional alteration of the geological units plays a role in the hydrogeological condition where the groundwater flow zones occur through fractures and cracks. Where, the low TDS concentrations in some groundwater samples reflect the fresh nature of the groundwater in this area of study. In other words, the lower values of the TDS are recording in wells being drilled in the carbonate rocks adjacent the El-Ibrahimia and Bahr Yousf canals. On the other hand, the high TDS concentration in some groundwater samples reflecting the brackish nature of the groundwater which is the normal case for the salinity of the carbonate aquifer.

\section{The hyrochemical coefficients (ion ratios)}

The expression of the ionic relationship in terms of mathematical ratios is quite helpful for establishing chemical similarities among waters, representing a single geologic terrain or single aquifer. Ion ratios are also useful in detection groundwater contamination (pollution) or mixing with other water sources. The ion ratios are important for possible determination of the origin of groundwater and the different processes contributing to water quality development.

\section{Sodium/chloride ratio $\left(\mathrm{rNa}^{+} / \mathrm{rCl}^{-}\right)$}

The value of this ratio expresses the sodium-chloride imbalance in water and it differs greatly according to the concentration of the total dissolved solids in water.

Most of the Eocene groundwater samples (62\%) in the study area have $\mathrm{rNa}^{+} / \mathrm{rCl}^{-}$ratio less than unity. The decrease in $\mathrm{Na}$ ion concentration may be attributed to the adsorption of sodium ions on the fine argillaceous sediments and mixing with marine water rich in chloride ions (Starinsky et al., 1983) as a result of the over pumping activities beside the effect of marine deposits of Eocene aquifer (Table 2). The rest of the Eocene groundwater samples (38\%) have values of $\mathrm{rNa}^{+} / \mathrm{rCl}^{-}$ratio more than unity reflecting meteoric water recharge, as Starinksky et al. (1983) concluded that the increasing in Na ions may be theoretically originated by dissolution of sodium bearing silicates from country rocks (Table 2). This is shown in figure (7), where the groundwater at west Samalut and west Abu Qurqas localities has $\mathrm{rNa}^{+} / \mathrm{rCl}^{-}$ion ratio more than unity reflecting that these localities are affected by the recharge from the irrigation canal (El-Ibrahimia and Bahr Yousf canals). 
Table 1: The concentrations of major constituents in surface water and groundwater at the study area (as $\mathrm{mg} / \mathrm{l}$ )

\begin{tabular}{|c|c|c|c|c|c|c|c|c|c|c|c|c|}
\hline $\begin{array}{l}\text { Sample } \\
\text { No. }\end{array}$ & $\begin{array}{c}\mathrm{EC} \\
(\mu \mathrm{s} / \mathrm{cm}) \\
\text { at } 25^{0} \mathrm{C}\end{array}$ & $\mathbf{p H}$ & TDS & $\mathrm{Ca}^{2+}$ & $\mathrm{Mg}^{2+}$ & $\mathrm{Na}^{+}$ & $\mathbf{K}^{+}$ & $\mathrm{CO}_{3}{ }^{2-}$ & $\mathrm{HCO}_{3}^{-}$ & $\mathrm{SO}_{4}{ }^{2-}$ & $\mathrm{Cl}^{-}$ & SAR \\
\hline \multicolumn{13}{|c|}{ Surface water } \\
\hline \multicolumn{13}{|c|}{ El-Ibrahimia canal } \\
\hline 1 & 306 & 6.7 & 148.27 & 19 & 11 & 20 & 5 & 0 & 130 & 13.49 & 14.78 & 1.28 \\
\hline \multicolumn{13}{|c|}{ Bahr Yousf canal } \\
\hline 2 & 307 & 7.1 & 166 & 22 & 12 & 21 & 5 & 0 & 128 & 31 & 12 & 0.98 \\
\hline \multicolumn{13}{|c|}{$\begin{array}{c}\text { Groundwater } \\
\text { aquifer (guidance }\end{array}$} \\
\hline 3 & 3100 & 7.3 & 205 & 20.04 & 6.07 & 34 & 12 & 9.9 & 67.11 & 33.62 & 46.09 & 2.45 \\
\hline 4 & 602 & 7.4 & 221 & 21.6 & 26.24 & 50 & 20 & 24.99 & 162.29 & 49.5 & 59.1 & 2.42 \\
\hline 5 & 675 & 7.3 & 394 & 34.86 & 43.16 & 28 & 9 & 0.33 & 345.53 & 5 & 39.4 & 1.06 \\
\hline 6 & 1650 & 7.3 & 3995 & 170.34 & 79.03 & 23 & 33 & 10 & 106.71 & 120.07 & 336.87 & 0.52 \\
\hline 7 & 472 & 7.3 & 287 & 28.05 & 22.85 & 23 & 13 & 0 & 173.88 & 55.934 & 24.63 & 1.11 \\
\hline 8 & 3040 & 7.3 & 1504 & 154.8 & 69.98 & 363 & 14 & 0 & 502.74 & 2.814 & 753.53 & 8.60 \\
\hline 9 & 1007 & 7.5 & 576 & 57.6 & 37.18 & 110 & 7 & 0 & 335.37 & 9 & 187.15 & 3.93 \\
\hline 10 & 8750 & 7.8 & 5689 & 172.6 & 66.8 & 1650 & 41 & 0 & 91.5 & 2050 & 1663.12 & 38.2 \\
\hline 11 & 699 & 7.3 & 196 & 32.4 & 23.95 & 71 & 5 & 29.99 & 157.41 & 33.99 & 83.73 & 3.27 \\
\hline 12 & 4320 & 7.3 & 768 & 151.1 & 126.45 & 589 & 22 & 19.99 & 233.74 & 3.4 & 1413 & 12.1 \\
\hline \multicolumn{13}{|c|}{ Eocene aquifer } \\
\hline 13 & 643 & 7.3 & 348 & 62.12 & 30.27 & 27 & 5 & 14.99 & 137.45 & 46.2 & 93.88 & 0.90 \\
\hline 14 & 3420 & 7.3 & 1843 & 86.4 & 65.61 & 562 & 0 & 19.99 & 279.47 & 4.9 & 964.88 & 15.69 \\
\hline 15 & 1973 & 7.4 & 1000 & 70.14 & 126.45 & 129 & 4 & 14.99 & 203.25 & 10.14 & 543.75 & 3.00 \\
\hline 16 & 765 & 7.4 & 378 & 44.08 & 36.06 & 53 & 6 & 19.99 & 238.51 & 37.1 & 62.76 & 2.02 \\
\hline 17 & 1367 & 7.4 & 711 & 102.6 & 33.43 & 97 & 5 & 10 & 132.11 & 40.52 & 355.81 & 3.02 \\
\hline 18 & 950 & 7.3 & 501 & 80.16 & 40 & 55 & 5 & 19.99 & 254.07 & 46.91 & 126.9 & 1.77 \\
\hline 19 & 563 & 7.3 & 294 & 40.68 & 35.62 & 20 & 5 & 10 & 188.95 & 29.3 & 59.1 & 0.78 \\
\hline 20 & 731 & 7.3 & 444 & 39.07 & 48.75 & 58 & 6 & 15 & 370.93 & 22.8 & 68.95 & 2.07 \\
\hline 21 & 1137 & 7.5 & 617 & 70.14 & 38.91 & 103 & 12 & 15 & 132.11 & 30.43 & 281.51 & 3.48 \\
\hline 22 & 870 & 7.4 & 440 & 70.94 & 27.84 & 59 & 5 & 25 & 223.3 & 33.15 & 107.09 & 2.12 \\
\hline 23 & 844 & 7.3 & 452 & 84.16 & 27.35 & 41 & 5 & 30 & 218.42 & 67.72 & 87.58 & 1.42 \\
\hline 24 & 728 & 7.4 & 383 & 32.4 & 24.06 & 77 & 6 & 20 & 233.74 & 33.112 & 73.88 & 3.51 \\
\hline 25 & 1087 & 7.3 & 557 & 36 & 21.87 & 150 & 6 & 15 & 269.31 & 30.93 & 162.53 & 6.88 \\
\hline 26 & 697 & 7.4 & 363 & 28.8 & 21.87 & 80 & 5 & 10 & 259.15 & 8.81 & 78.8 & 3.87 \\
\hline 27 & 1529 & 7.3 & 826 & 68.4 & 34.99 & 193 & 7 & 0 & 213.41 & 41.223 & 374.3 & 6.70 \\
\hline 28 & 2990 & 7 & 1544 & 82.8 & 45.93 & 460 & 11 & 10 & 233.74 & 4.97 & 812.63 & 14.23 \\
\hline 29 & 1068 & 7.5 & 584 & 36 & 24.06 & 152 & 5 & 15 & 289.81 & 29.66 & 177.3 & 6.81 \\
\hline 30 & 702 & 7.4 & 405 & 43.2 & 21.87 & 86 & 6 & 2 & 279.47 & 10.265 & 98.5 & 3.74 \\
\hline 31 & 1269 & 7.3 & 680 & 54 & 21.87 & 173 & 7 & 2 & 335.37 & 10.282 & 246.25 & 7.11 \\
\hline 32 & 1263 & 7.4 & 665 & 50.4 & 43.74 & 147 & 7 & 2 & 264.23 & 38.89 & 246.25 & 5.16 \\
\hline 33 & 921 & 7.3 & 534 & 43.2 & 17.5 & 135 & 8 & 2 & 335.37 & 9.912 & 152.68 & 6.19 \\
\hline 34 & 790 & 7.6 & 410 & 36 & 30.62 & 73 & 3 & 5 & 243.9 & 21.16 & 118.2 & 3.07 \\
\hline 35 & 1654 & 7.4 & 955 & 50.4 & 30.62 & 280 & 6 & 2 & 355.69 & 15.62 & 394 & 10.86 \\
\hline 36 & 3340 & 7.4 & 1945 & 118.8 & 52.49 & 560 & 8 & 2 & 325.2 & 21.27 & 1022 & 15.22 \\
\hline 37 & 917 & 7.6 & 481 & 72.34 & 60.43 & 24 & 5 & 45 & 208.05 & 37.77 & 131.91 & 0.71 \\
\hline 38 & 894 & 7.5 & 517 & 64.8 & 13.12 & 120 & 6 & 2 & 320.12 & 5.3 & 147.75 & 5.02 \\
\hline 39 & 1979 & 7.3 & 1018 & 93.6 & 61.24 & 258 & 10 & 2 & 279.47 & 1.95 & 453.1 & 7.21 \\
\hline 40 & 3820 & 7.3 & 2211 & 50.4 & 34.99 & 800 & 9 & 15 & 711.4 & 10.354 & 935.75 & 29.97 \\
\hline 41 & 3480 & 7.3 & 1905 & 108 & 56.86 & 556 & 10 & 1 & 610.12 & 6.969 & 861.88 & 15.24 \\
\hline 42 & 1043 & 6.6 & 553 & 42.02 & 30.07 & 128 & 5 & 1 & 210.45 & 51.348 & 190.97 & 5.21 \\
\hline 43 & 1592 & 7.3 & 1057 & 119.1 & 35.4 & 200 & 6 & 15 & 128.1 & 254.7 & 362.35 & 5.85 \\
\hline 44 & 1144 & 7.2 & 755 & 130 & 29.88 & 100 & 6 & 15 & 158.6 & 170 & 225.24 & 2.91 \\
\hline 45 & 8780 & 7.3 & 6164 & 807.1 & 38.84 & 1420 & 6 & 15 & 167.75 & 1100 & 2693.10 & 18.74 \\
\hline 46 & 2394 & 6.7 & 1345 & 82.8 & 45.93 & 363 & 26 & 2 & 518.29 & 25.867 & 541.75 & 11.23 \\
\hline 47 & 1305 & 7.5 & 683 & 60.12 & 58.36 & 120 & 6 & 20 & 269.31 & 23.69 & 261.03 & 3.72 \\
\hline 48 & 6200 & 7.3 & 3204 & 597.6 & 376.16 & 36 & 25 & 20 & 254.07 & 2.62 & 2019.25 & 0.40 \\
\hline 49 & 1587 & 7.4 & 873 & 64.8 & 26.24 & 233 & 9 & 0 & 304.88 & 43.051 & 344.75 & 8.74 \\
\hline 50 & 825 & 7.4 & 457 & 62.12 & 30.39 & 70 & 5 & 10 & 243.44 & 34.9 & 123.13 & 2.57 \\
\hline 51 & 3630 & 6.8 & 2266 & 127.8 & 62.82 & 600 & 13 & 12 & 94.55 & 668.16 & 734.48 & 15.37 \\
\hline 52 & 6650 & 7.1 & 4062 & 311.3 & 109.6 & 1050 & 13 & 12 & 91.5 & 700 & 1820 & 18.44 \\
\hline 53 & 1318 & 7.5 & 723 & 39.9 & 27.15 & 195 & 5 & 27 & 106.75 & 101.11 & 274.2 & 8.25 \\
\hline 54 & 1200 & 7.4 & 647 & 51.63 & 30.84 & 155 & 5 & 12 & 195.2 & 60 & 235.03 & 5.96 \\
\hline
\end{tabular}


Cont. Table 1.

\begin{tabular}{|c|c|c|c|c|c|c|c|c|c|c|c|c|}
\hline $\begin{array}{c}\text { Sample } \\
\text { No. }\end{array}$ & $\begin{array}{c}\text { EC } \\
(\mu \mathrm{m} / \mathrm{cm})\end{array}$ & pH & TDS & $\mathrm{Ca}^{2+}$ & $\mathbf{M g}^{2+}$ & $\mathbf{N a}^{+}$ & $\mathbf{K}^{+}$ & $\mathrm{CO}_{3}{ }^{2-}$ & $\mathrm{HCO}_{3}^{-}$ & $\mathrm{SO}_{4}{ }^{2-}$ & $\mathrm{Cl}^{-}$ & SAR \\
\hline \multicolumn{13}{|c|}{ Eocene aquifer } \\
\hline 55 & 1551 & 7.1 & 890 & 69.33 & 34.42 & 210 & 6 & 15 & 137.25 & 153.64 & 332.97 & 7.29 \\
\hline 56 & 2165 & 7.4 & 1237 & 40.63 & 35.26 & 360 & 6 & 12 & 128.1 & 195.21 & 523.93 & 14.11 \\
\hline 57 & 1884 & 7.1 & 1237 & 129.1 & 42.1 & 210 & 9 & 24 & 125.05 & 550 & 210.55 & 5.81 \\
\hline 58 & 1883 & 7.3 & 1164 & 89.73 & 44.25 & 260 & 7 & 30 & 115.9 & 336.71 & 337.995 & 7.94 \\
\hline 59 & 1433 & 7.5 & 873 & 68.61 & 36.33 & 195 & 5 & 0 & 195.2 & 210 & 260.74 & 6.70 \\
\hline 60 & 2490 & 7.3 & 1393 & 90.1 & 60 & 350 & 7 & 21 & 122 & 210 & 593.91 & 9.92 \\
\hline 61 & 4140 & 7.3 & 2517 & 78.99 & 43.56 & 720 & 15 & 21 & 164.7 & 931.48 & 624.31 & 22.84 \\
\hline 62 & 986 & 7.2 & 638 & 72.55 & 22.29 & 110 & 7 & 21 & 173.85 & 240 & 78.34 & 4.1 \\
\hline 63 & 1328 & 7.4 & 814 & 79.24 & 36.37 & 140 & 7 & 30 & 137.25 & 330 & 122.41 & 4.62 \\
\hline 64 & 1539 & 7.5 & 827 & 70.26 & 39.55 & 185 & 6 & 24 & 134.2 & 131.015 & 304.2 & 6.19 \\
\hline 65 & 1436 & 7.4 & 794 & 70.67 & 37.07 & 170 & 6 & 12 & 164.7 & 160 & 255.91 & 5.77 \\
\hline 66 & 1485 & 6.9 & 827 & 70 & 32 & 190 & 6 & 18 & 152.5 & 140 & 294.54 & 6.68 \\
\hline 67 & 2142 & 7.4 & 1210 & 76.05 & 51.97 & 280 & 7 & 15 & 173.85 & 220.11 & 473.19 & 8.58 \\
\hline 68 & 2260 & 7.2 & 1265 & 85.6 & 62.13 & 300 & 7 & 24 & 167.75 & 200 & 502.164 & 8.52 \\
\hline 69 & 1753 & 7.4 & 1004 & 75.17 & 44.38 & 230 & 7 & 15 & 167.75 & 186.38 & 362.14 & 7.36 \\
\hline 70 & 3160 & 7.3 & 1624 & 102.4 & 51.04 & 420 & 8 & 9 & 167.75 & 239.48 & 710 & 11.98 \\
\hline 71 & 1652 & 7.3 & 986 & 71.21 & 40.97 & 240 & 6 & 30 & 140.3 & 190 & 337.995 & 7.94 \\
\hline 72 & 2286 & 7.2 & 1271 & 80.12 & 46.56 & 310 & 8 & 0 & 207.4 & 224.72 & 497.34 & 9.64 \\
\hline 73 & 1892 & 7.6 & 1053 & 54.58 & 46.53 & 280 & 7 & 18 & 167.75 & 137.91 & 424.91 & 9.52 \\
\hline 74 & 6720 & 7.2 & 3514 & 206.7 & 128.9 & 900 & 21 & 15 & 152.5 & 354.86 & 1810.69 & 17.12 \\
\hline 75 & 2277 & 7.4 & 1228 & 73.8 & 46.35 & 300 & 9 & 15 & 167.75 & 190.29 & 509.24 & 9.54 \\
\hline 76 & 1572 & 7.3 & 962 & 106.1 & 40.27 & 190 & 6 & 21 & 97.6 & 196.805 & 352.55 & 5.64 \\
\hline 77 & 3510 & 7.2 & 1969 & 124 & 67.38 & 480 & 12 & 18 & 167.75 & 338.64 & 844.66 & 12.19 \\
\hline 78 & 2904 & 7.2 & 1694 & 128.2 & 57.1 & 400 & 11 & 15 & 183 & 220 & 771.21 & 10.45 \\
\hline 79 & 5540 & 7.2 & 2785 & 109.3 & 100.2 & 770 & 17 & 15 & 173.85 & 168.6 & 1517.93 & 18.10 \\
\hline 80 & 5440 & 7.3 & 3202 & 153.2 & 119.9 & 820 & 17 & 15 & 183 & 479.62 & 1505.69 & 17.05 \\
\hline 81 & 6710 & 7.2 & 3860 & 198.2 & 121.2 & 1000 & 23 & 15 & 152.5 & 614.78 & 1811.72 & 19.52 \\
\hline 82 & 8680 & 7.2 & 5009 & 230 & 158 & 1360 & 23 & 15 & 143.35 & 604.76 & 2546 & 23.92 \\
\hline 83 & 4030 & 7.3 & 1938 & 122.7 & 79.49 & 520 & 15 & 15 & 183 & 54.12 & 1040.52 & 12.72 \\
\hline 84 & 11970 & 7.2 & 6816 & 321.7 & 188.6 & 1850 & 29 & 15 & 112.85 & 976.6 & 3378.62 & 28.65 \\
\hline 85 & 5780 & 7.4 & 3048 & 153 & 113.7 & 820 & 20 & 15 & 106.75 & 232.12 & 1640.35 & 17.31 \\
\hline 86 & 7570 & 7.2 & 3677 & 223.4 & 132.1 & 950 & 22 & 15 & 122 & 241.2 & 2032.07 & 17.62 \\
\hline
\end{tabular}

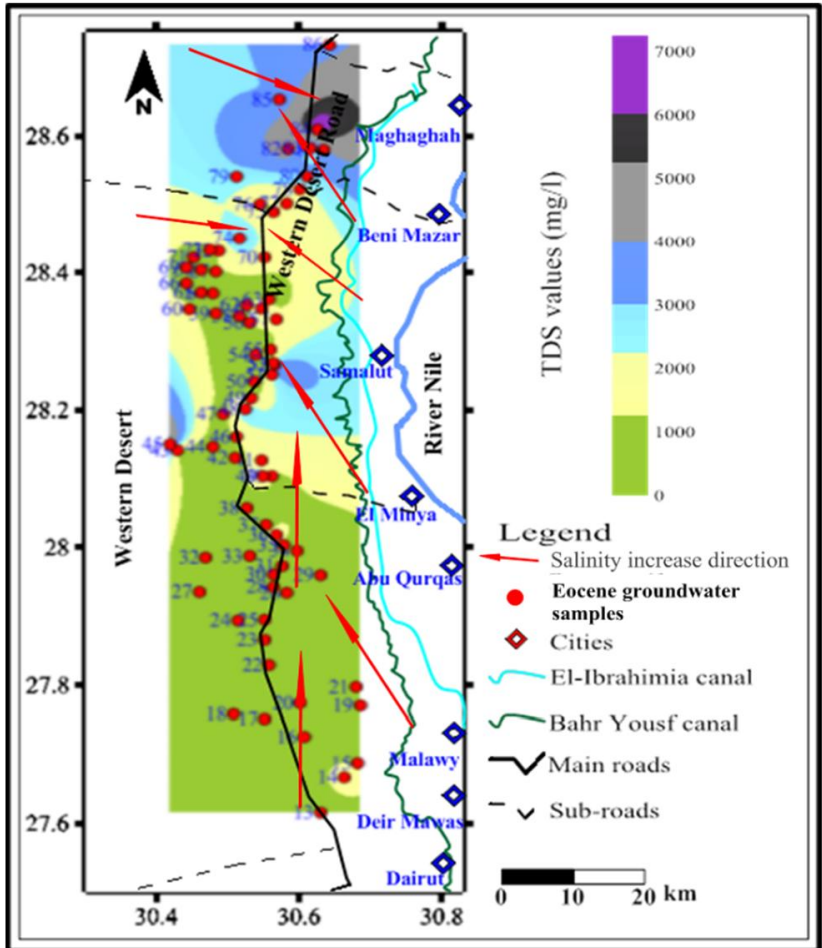

Fig. 6:TDS contour map of the Eocene groundwater at the study area 


\section{Sulfate/chloride ratio $\left(\mathrm{rSO}_{4}{ }^{2-} / \mathrm{rCl}^{-}\right)$}

This ratio could be taken as a guide for detecting any excess of sulfate in groundwater associated with sulfate mineral dissolution. The solubility of the sulfate mineral components gradually increased the hierarchical composition with depth and distance from the recharge area (Burden, 1958). Consequently, the percolation of meteoric water and the greater distance of recharge area are the main factors of increasing the sulfate concentration by direct action of leaching processes. Most of the Eocene groundwater samples $(69 \%)$ in the study area have $\mathrm{rSO}_{4}{ }^{2-} / \mathrm{rCl}^{-}$ratio values more than that of the sea water $(0.1)$ as shown in Table 2 and figure 8 . This reflects the dissolution of a local terrestrial source of sulfate such as gypsum $\left(\mathrm{CaSO}_{4} \cdot 2 \mathrm{H}_{2} \mathrm{O}\right)$, epsomite $\left(\mathrm{MgSO}_{4} .7 \mathrm{H}_{2} \mathrm{O}\right)$, glauberite $\left(\mathrm{Na}_{2} \mathrm{SO}_{4} \cdot 10 \mathrm{H}_{2} \mathrm{O}\right)$ and anhydrite $\left(\mathrm{CaSO}_{4}\right)$. The rest of the Eocene groundwater samples $(31 \%)$ have $\mathrm{rSO}_{4}{ }^{2-} / \mathrm{rCl}^{-}$ratio values less than that of the sea water $(0.1)$ as shown in Table 2 and figure 8 . This is rendered to the effect of the marine deposits of the Eocene formation on the groundwater in the study area.

Table 2: The hydrochemical facies of the Eocene groundwater samples in the study area

\begin{tabular}{|c|c|c|c|c|c|c|c|}
\hline $\begin{array}{c}\text { Sample } \\
\text { No. }\end{array}$ & $\mathbf{r N a}^{+} / \mathbf{r C l}^{-}$ & $\mathrm{rSO}_{4}{ }^{2-} / \mathrm{rCl}^{-}$ & $\mathrm{rCa}^{2+} / \mathrm{rMg}^{2+}$ & $\begin{array}{c}\text { Sample } \\
\text { No. }\end{array}$ & $\mathbf{r N a}^{+} / \mathbf{r C l}^{-}$ & $\mathrm{rSO}_{4}{ }^{2-} / \mathrm{rCl}^{-}$ & $\mathrm{rCa}^{2+} / \mathrm{rMg}^{2+}$ \\
\hline 13 & 0.490 & 0.363 & 1.245 & 51 & 1.276 & 0.672 & 1.234 \\
\hline 14 & 0.898 & 0.004 & 0.799 & 52 & 0.896 & 0.284 & 1.723 \\
\hline 15 & 0.372 & 0.014 & 0.337 & 53 & 1.114 & 0.272 & 0.892 \\
\hline 16 & 1.387 & 0.436 & 0.742 & 54 & 1.037 & 0.188 & 1.016 \\
\hline 17 & 0.434 & 0.084 & 1.862 & 55 & 0.989 & 0.341 & 1.222 \\
\hline 18 & 0.704 & 0.273 & 1.216 & 56 & 1.070 & 0.275 & 0.699 \\
\hline 19 & 0.599 & 0.366 & 0.693 & 57 & 1.577 & 1.929 & 1.861 \\
\hline 20 & 1.377 & 0.244 & 0.486 & 58 & 1.205 & 0.735 & 1.230 \\
\hline 21 & 0.606 & 0.080 & 1.094 & 59 & 1.171 & 0.595 & 1.146 \\
\hline 22 & 0.890 & 0.229 & 1.546 & 60 & 0.919 & 0.261 & 0.911 \\
\hline 23 & 0.780 & 0.571 & 1.867 & 61 & 1.801 & 1.102 & 1.100 \\
\hline 24 & 1.673 & 0.331 & 0.817 & 62 & 2.247 & 2.262 & 1.974 \\
\hline 25 & 1.457 & 0.141 & 0.999 & 63 & 1.816 & 1.990 & 1.322 \\
\hline 26 & 1.624 & 0.083 & 0.799 & 64 & 0.956 & 0.318 & 1.077 \\
\hline 27 & 0.813 & 0.081 & 1.186 & 65 & 0.684 & 0.462 & 1.048 \\
\hline 28 & 0.885 & 0.005 & 1.094 & 66 & 1.014 & 0.351 & 1.327 \\
\hline 29 & 1.350 & 0.124 & 0.908 & 67 & 0.926 & 0.343 & 0.888 \\
\hline 30 & 1.394 & 0.077 & 1.199 & 68 & 0.934 & 0.294 & 0.836 \\
\hline 31 & 1.110 & 0.031 & 1.498 & 69 & 0.997 & 0.380 & 1.028 \\
\hline 32 & 0.944 & 0.117 & 0.699 & 70 & 0.923 & 0.249 & 1.217 \\
\hline 33 & 1.411 & 0.048 & 1.498 & 71 & 1.111 & 0.415 & 1.055 \\
\hline 34 & 0.979 & 0.132 & 0.713 & 72 & 0.976 & 0.334 & 1.044 \\
\hline 35 & 1.110 & 0.029 & 0.999 & 73 & 1.031 & 0.240 & 0.712 \\
\hline 36 & 0.852 & 0.015 & 1.373 & 74 & 0.709 & 0.145 & 1.026 \\
\hline 37 & 0.315 & 0.211 & 0.726 & 75 & 0.925 & 0.276 & 0.966 \\
\hline 38 & 1.288 & 0.026 & 2.997 & 76 & 0.847 & 0.412 & 1.599 \\
\hline 39 & 0.899 & 0.003 & 0.927 & 77 & 0.889 & 0.296 & 1.117 \\
\hline 40 & 1.327 & 0.008 & 0.874 & 78 & 0.813 & 0.211 & 1.362 \\
\hline 41 & 1.005 & 0.006 & 1.152 & 79 & 0.793 & 0.082 & 0.662 \\
\hline 42 & 1.058 & 0.199 & 0.848 & 80 & 0.851 & 0.235 & 0.775 \\
\hline 43 & 0.866 & 0.519 & 2.041 & 81 & 0.863 & 0.251 & 0.992 \\
\hline 44 & 0.709 & 0.557 & 2.639 & 82 & 0.832 & 0.175 & 0.883 \\
\hline 45 & 0.815 & 0.306 & 12.609 & 83 & 0.784 & 0.038 & 0.937 \\
\hline 46 & 1.077 & 0.035 & 1.094 & 84 & 0.852 & 0.213 & 1.035 \\
\hline 47 & 0.727 & 0.067 & 0.625 & 85 & 0.782 & 0.104 & 0.816 \\
\hline 48 & 0.039 & 0.001 & 0.964 & 86 & 0.731 & 0.088 & 1.026 \\
\hline 49 & 1.067 & 0.092 & 1.498 & & & & \\
\hline 50 & 0.912 & 0.209 & 1.240 & & & & \\
\hline
\end{tabular}

Jacobson and Langmuir (1970) reported that the ratio of $\mathrm{Ca}^{2+} / \mathrm{Mg}^{2+}$ gives certain indications with regard to the nature of the carbonate aquifer, when this ratio has a value close to unity, it is concluded 
that groundwater is flowing entirely through dolomite terrain. However, when the $\mathrm{Ca}^{2+} / \mathrm{Mg}^{2+}$ ratio is equal to or greater than four, the groundwater is likely to flow in pure limestone (Meisler and Becher, 1967). About $52 \%$ of the Eocene groundwater samples have $\mathrm{rCa}^{2+} / \mathrm{rMg}^{2+}$ ratio more than unity and less than four, except for sample No.45 where $\left(\mathrm{rCa}^{2+} / \mathrm{rMg}^{2+}\right)$ is more than four regardless of their water salinities. This means that $\mathrm{Ca}^{2+}$ exceeds $\mathrm{Mg}^{2+}$, indicating that groundwater is likely flowed entirely through dolomitic-limestone terrain within the aquifer matrices as well as these groundwater samples are mainly recharged from the surface water (irrigation canals), where calcium ions exceed the magnesium ones in the surface water samples. On the other hand, the rest of the Eocene groundwater samples $(48 \%)$ have $\left(\mathrm{rCa}^{2+} / \mathrm{rMg}^{2+}\right)$ ratio less than unity regardless of their water salinities. This means that $\mathrm{Mg}^{2+}$ exceeds $\mathrm{Ca}^{2+}$, indicating the precipitation of $\mathrm{Ca}$ ions as calcium carbonate or sulfate in the pore spaces of rooks due to the long distance of the water flow path (Hem, 1989), (Table 2 and Figure 9).

In conclusion, the ionic ratios indicated that, the investigated groundwater has different mineralization sources due to leaching, dissolution and cation exchange processes.

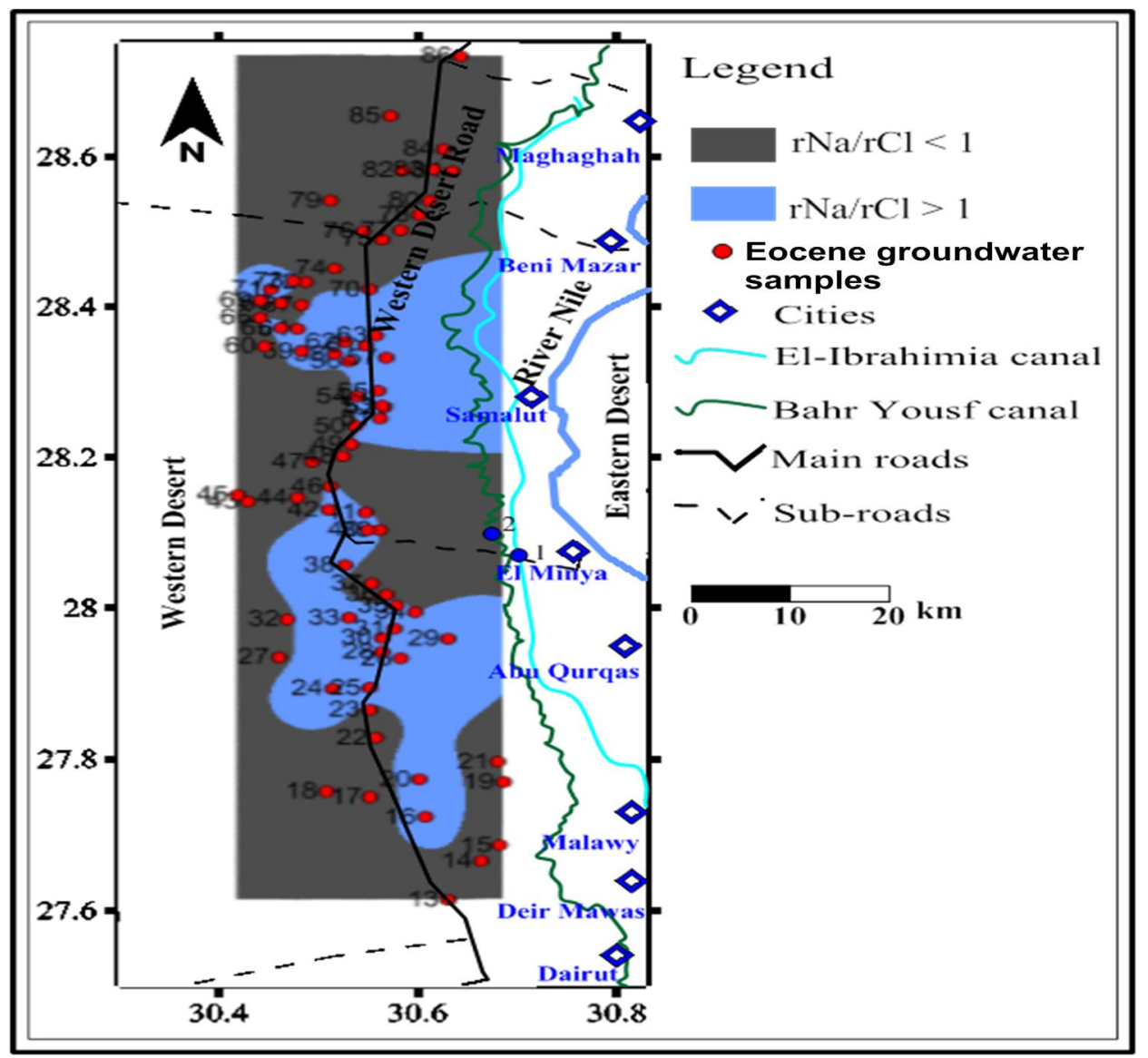

Fig.7: $\mathrm{The}_{\mathrm{rNa}}+/ \mathrm{rCl}^{-}$ion ratio distribution map of the Eocene groundwater in the study area 


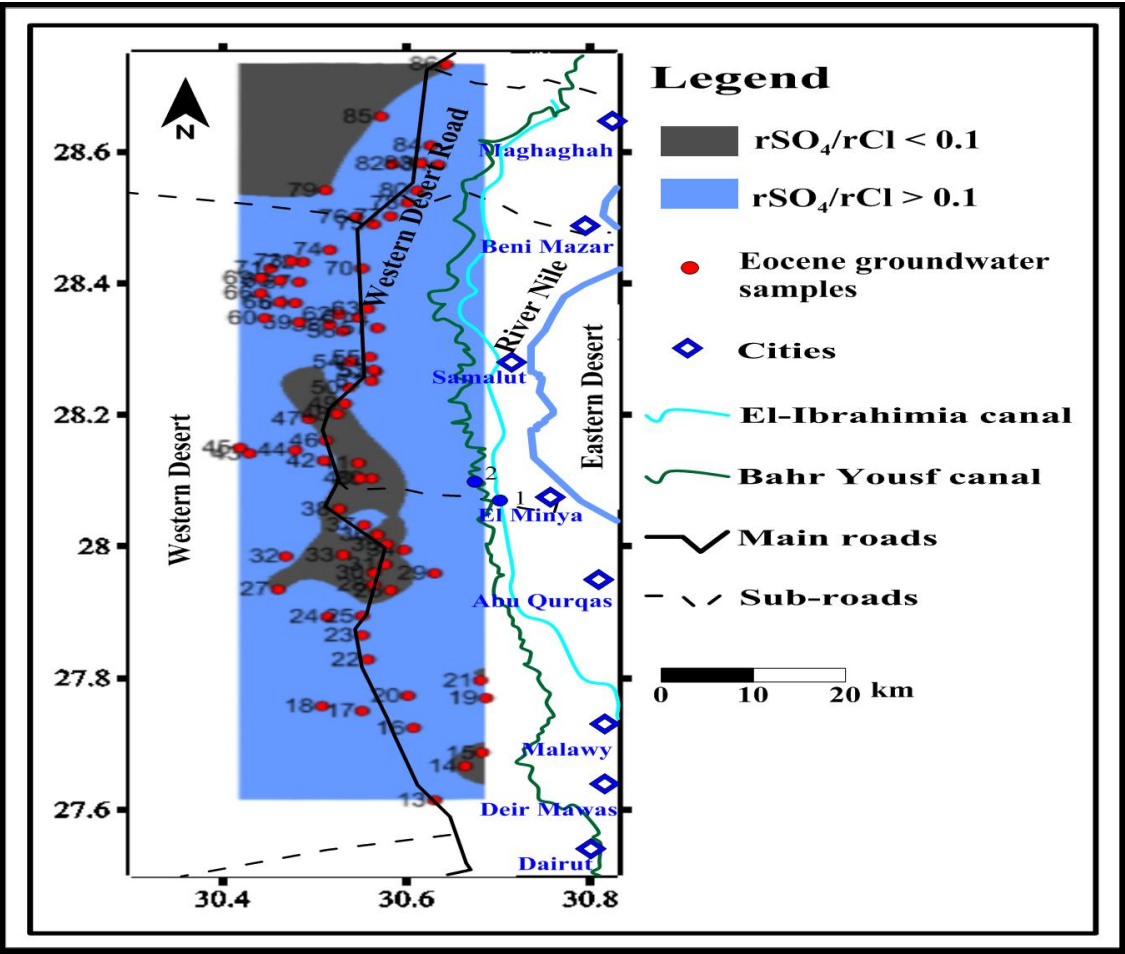

Fig. 8: The $\mathrm{rSO}_{4}{ }^{2-} / \mathrm{rCl}^{-}$ion ratio distribution map of the Eocene groundwater in the study area. Calcium/magnesium ratio $\left(\mathrm{rCa}^{2+} / \mathrm{rMg}^{2+}\right)$

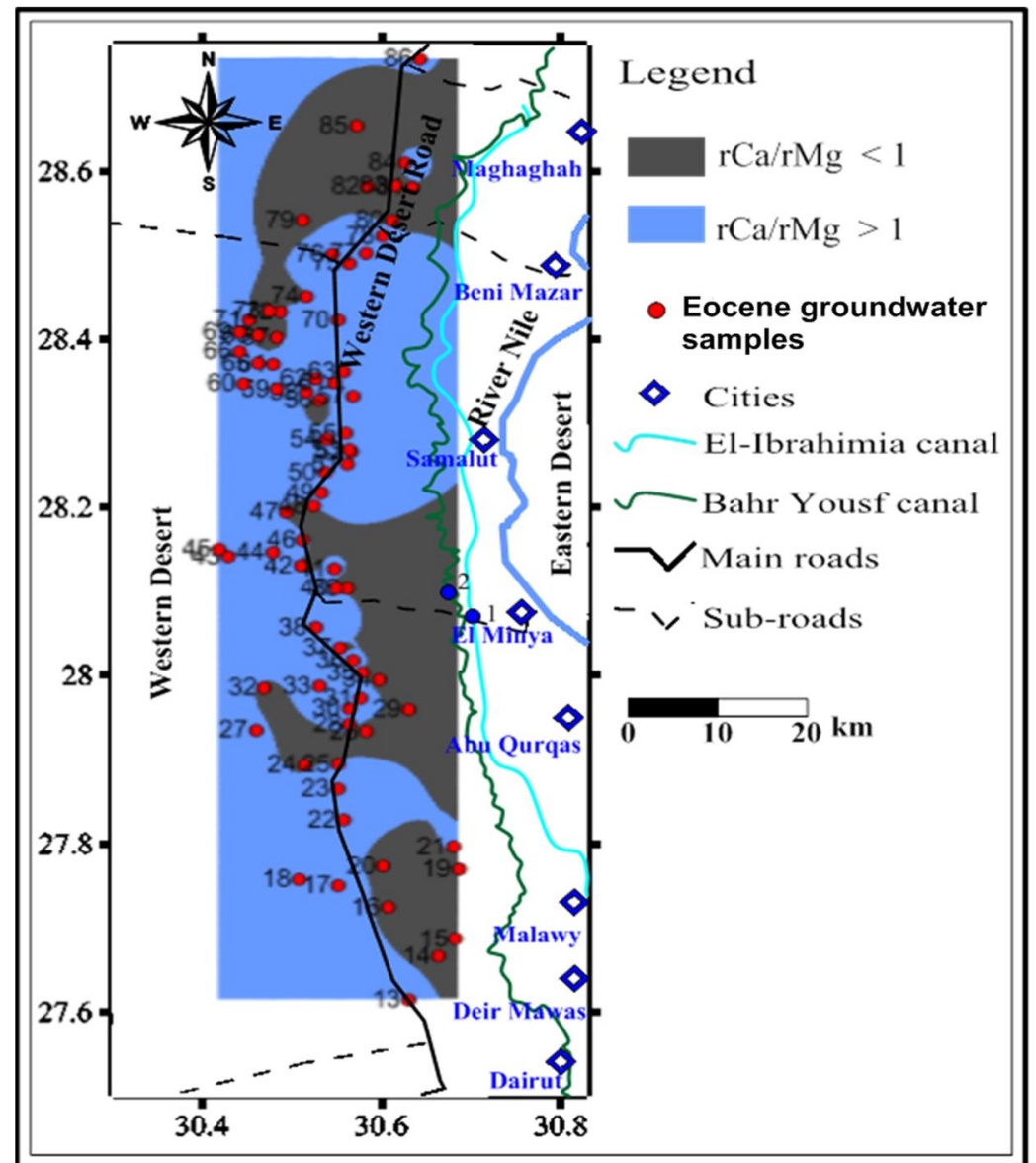

Fig. 9: $\mathrm{The}_{\mathrm{rCa}} \mathrm{Ca}^{2+} \mathrm{rgg}^{2+}$ ion ratio distribution map of the Eocene groundwater in the study area 


\section{The hydrochemical facies}

Based on the ion relationships between the surface water (irrigation canals) and the Eocene groundwater as well as the selected groundwater samples of the Pleistocene aquifer (Table 3), it can be concluded that;

For the irrigation canals (El-Ibrahimia and Bahr Yousf canals), two hydrochemical facies are recogonized, namely; $\mathrm{HCO}_{3}{ }^{-}>\mathrm{SO}_{4}{ }^{2-}>\mathrm{Cl}^{-}$and $\mathrm{HCO}_{3}{ }^{-}>\mathrm{Cl}^{-}>\mathrm{SO}_{4}{ }^{2-}$ (early stage of hydrochemical evolution), regardless of their magnitudes.

The majority of the selected groundwater samples of the Pleistocene aquifer (70\%) and $23 \%$ of the Eocene aquifer groundwater samples in the study area have less chemically developed stage $\left(\mathrm{HCO}_{3}{ }^{-}>\mathrm{Cl}^{-}>\mathrm{SO}_{4}{ }^{2-}\right)$ where the $\mathrm{HCO}_{3}{ }^{-}$ion is the dominant anion and the common assemblage hypothetical salts are I, II, IV. These hydrochemical facies and detected hypothetical salts combinations assemblages are representing the groundwater of continental facies which requires its quality from the leaching and dissolution of the aquifer matrix through the recharge from surface water (El-Ibrahimia and Bahr Yousf canals). This confirms that the Eocene aquifer may be recharged from the irrigation canals and from the upper Pleistocene aquifer at some localities.

The majority of the Eocene groundwater samples $(69 \%)$ and $30 \%$ of the selected groundwater samples of the Pleistocene aquifer have more chemically evoluted sequence $\left(\mathrm{Cl}^{-}>\mathrm{SO}_{4}{ }^{2-}>\mathrm{HCO}_{3}{ }^{-}\right.$ and $\mathrm{Cl}^{-}>\mathrm{HCO}_{3}{ }^{-}>\mathrm{SO}_{4}{ }^{2-}$, where, $\mathrm{Cl}^{-}$ion is the dominant anion and the common hypothetical salts are (III, IV and VI) and (I, II, III, IV, V, VI) for the Pleistocene and Eocene aquifers, respectively. Such hydrochemical facies and hypothetical salts are representing the groundwater of continental and marine facies, resulting in a specific ion relationship with a prominent increase in total salinity due to terrestrial and marine salt dissolution. Also, the similarity in the hydrochemical facies and hypothetical salts leads to that there is a hydraulic connection between the Pleistocene and Eocene aquifers in some localities at the study area.

The rest of the Eocene groundwater samples (8\%) in the study area have an intermediate metasomatic sequence $\left(\mathrm{SO}_{4}{ }^{2-}>\mathrm{Cl}^{-}>\mathrm{HCO}_{3}{ }^{-}\right.$and $\left.\mathrm{SO}_{4}{ }^{2-}>\mathrm{HCO}_{3}{ }^{-}>\mathrm{Cl}^{-}\right)$, where the $\mathrm{SO}_{4}{ }^{2-}$ ion is the dominant anion, indicating the leaching and dissolution processes of terrestrial salts especially sulfate minerals beside cation exchange process.

\section{The assemblages of hypothetical salts combinations}

The combination between major anions and cations reveals the formation of six main groups of hypothetical salts combinations in the irrigation canals (El-Ibrahimia and Bahr Yousf canals) and the Pleistocene aquifer (selected samples) as well as the Eocene aquifer groundwater samples in the study area (Table 3 and Fig.10).

Regarding hypothetical salts combination in El-Ibrahimia and Bahr yousf canals water, one main assemblage is detected (I) as in table (3). The presence of $\mathrm{Na}_{2} \mathrm{SO}_{4}$ salt in this assemblage is a true indication of dissolution of terrestrial salts from continental deposits. The presence of $\mathrm{NaHCO}_{3}$, $\mathrm{Mg}\left(\mathrm{CO}_{3}\right)_{2}$ and $\mathrm{Ca}\left(\mathrm{CO}_{3}\right)_{2}$ salts is considered as an indicator for the meteoric water. Therefore, such water acquires its chemical composition as a result of leaching and dissolution processes of terrestrial salts.

In the Pleistocene aquifer (selected groundwater samples) and Eocene groundwater, five and six main groups of salts combinations are distinguished respectively (Table 3 and Figure 10). With regard to the groundwater samples (50\% and $26 \%$ ) of the Pleistocene and Eocene aquifers, respectively, are characterized by the assemblages of hypothetical salts combinations (I and II) which characterized the water of the irrigation canals $\left[\mathrm{NaHCO}_{3}, \mathrm{Mg}\left(\mathrm{CO}_{3}\right)_{2}\right.$ and $\left.\mathrm{Ca}\left(\mathrm{CO}_{3}\right)_{2}\right]$. This confirms that the recharging process is mainly from the irrigation canals to the two concerned aquifers at some localities in the study area. This is clear from Fig.10, where there is a recharge from the irrigation canals at west Malawy, west Abu Qurqas, west El-Minya and west Samalut localities. Also, 10\% and 12\% of the groundwater samples of the Pleistocene and Eocene aquifers, respectively, table (3), are characterized by the assemblage of hypothetical salts combination (III), regardless of their total salinities. This reflects the effect of leaching and dissolution of terrestrial salts (continental facies groundwater) as well as downward infiltration of the excess irrigation water of cultivated soils (return flow after irrigation), this leads to the increase of water salinity. Also, this confirms the hydraulic connection between the two aquifers. 
On the other hand, $20 \%$ and $19 \%$ of the groundwater samples of the Pleistocene and Eocene aquifers, respectively, are characterized by the assemblage of hypothetical salts combination (IV), regardless of their total salinities. This assemblage (IV) includes two chloride and two bicarbonate salts, reflecting the effect of both terrestrial and marine salts (mixed facies groundwater). Also, this indicates that the Eocene aquifer is recharged from the upper Pleistocene aquifer.

In conclusion, the presence of the assemblages of the hypothetical salts combinations (II, III and IV) in both the Pleistocene and Eocene groundwater samples (50\% and 39\%, respectively) indicates that there is a hydraulic connection between the two aquifers in the study area. This is confirmed from the overlap between the areas occupied by the hypothetical salts combinations assemblage (II, III and IV) in the two aquifers groundwater samples in the study area (Fig.10).

Table 3: The hypothetical salts combinations and the hydrochemical facies of the surface water (irrigation canals) and groundwater (Pleistocene and Eocene aquifers) samples in the study area

\begin{tabular}{|c|c|c|}
\hline Assemblages of hypothetical salts combinations & Percentage & Hydrochemical facies \\
\hline \multicolumn{3}{|c|}{ Irrigation canals water samples (El Ibrahimia and Bahr Yousf canals) } \\
\hline $\begin{array}{l}\mathrm{I}-\mathrm{NaCl}, \mathrm{Na}_{2} \mathrm{SO}_{4}, \mathrm{NaHCO}_{3}, \mathrm{Mg}\left(\mathrm{HCO}_{3}\right)_{2} \text { and } \\
\mathrm{Ca}\left(\mathrm{HCO}_{3}\right)_{2}\end{array}$ & $100 \%$ & $\mathrm{HCO}_{3}{ }^{-}>\mathrm{SO}_{4}{ }^{2-}>\mathrm{Cl}^{-}$and $\mathrm{HCO}_{3}{ }^{-}>\mathrm{Cl}^{-}>\mathrm{SO}_{4}{ }^{2-}$ \\
\hline \multicolumn{3}{|c|}{ Pleistocene groundwater (guidance samples) } \\
\hline $\mathrm{I}-\mathrm{NaCl}, \mathrm{Na}_{2} \mathrm{SO}_{4}, \mathrm{NaHCO}_{3}, \mathrm{Mg}\left(\mathrm{HCO}_{3}\right)_{2}$ and $\mathrm{Ca}\left(\mathrm{HCO}_{3}\right)_{2}$ & $30 \%$ & $\mathrm{HCO}_{3}^{-}>\mathrm{Cl}^{-}>\mathrm{SO}_{4}^{2-}$ \\
\hline $\mathrm{II}-\mathrm{NaCl}, \mathrm{Na}_{2} \mathrm{SO}_{4}, \mathrm{MgSO}_{4}, \mathrm{Mg}\left(\mathrm{HCO}_{3}\right)_{2}$ and $\mathrm{Ca}\left(\mathrm{HCO}_{3}\right)_{2}$ & $20 \%$ & $\mathrm{HCO}_{3}{ }^{-}>\mathrm{SO}_{4}{ }^{2-}>\mathrm{Cl}^{-}$and $\mathrm{HCO}_{3}^{-}>\mathrm{Cl}^{-}>\mathrm{SO}_{4}{ }^{2-}$ \\
\hline III- $\mathrm{NaCl}, \mathrm{Na}_{2} \mathrm{SO}_{4}, \mathrm{MgSO}_{4}, \mathrm{CaSO}_{4}$ and $\mathrm{Ca}\left(\mathrm{HCO}_{3}\right)_{2}$ & $10 \%$ & $\mathrm{Cl}^{-}>\mathrm{SO}_{4}^{2-}>\mathrm{HCO}_{3}^{-}$ \\
\hline IV- $\mathrm{NaCl}, \mathrm{MgCl}_{2}, \mathrm{MgSO}_{4}, \mathrm{Mg}\left(\mathrm{HCO}_{3}\right)_{2}$ and $\mathrm{Ca}\left(\mathrm{HCO}_{3}\right)_{2}$ & $20 \%$ & $\mathrm{HCO}_{3}^{-}>\mathrm{Cl}^{-}>\mathrm{SO}_{4}{ }^{2-}$ and $\mathrm{Cl}^{-}>\mathrm{HCO}_{3}^{-}>\mathrm{SO}_{4}{ }^{2-}$ \\
\hline VI- $\mathrm{NaCl}, \mathrm{MgCl}_{2}, \mathrm{CaCl}_{2}, \mathrm{CaSO}_{4}$ and $\mathrm{Ca}\left(\mathrm{HCO}_{3}\right)_{2}$ & $20 \%$ & $\mathrm{Cl}^{-}>\mathrm{HCO}_{3}^{-}>\mathrm{SO}_{4}^{2-}$ and $\mathrm{Cl}^{-}>\mathrm{SO}_{4}^{2-}>\mathrm{HCO}_{3}^{-}$ \\
\hline \multicolumn{3}{|c|}{ Eocene groundwater samples } \\
\hline $\begin{array}{l}\mathrm{I}-\mathrm{NaCl}, \mathrm{Na}_{2} \mathrm{SO}_{4}, \mathrm{NaHCO}_{3}, \mathrm{Mg}\left(\mathrm{HCO}_{3}\right)_{2} \text { and } \\
\mathrm{Ca}\left(\mathrm{HCO}_{3}\right)_{2}\end{array}$ & $18 \%$ & $\mathrm{HCO}_{3}{ }^{-}>\mathrm{Cl}^{-}>\mathrm{SO}_{4}{ }^{2-}$ and $\mathrm{Cl}^{-}>\mathrm{HCO}_{3}{ }^{-}>\mathrm{SO}_{4}{ }^{2-}$ \\
\hline $\mathrm{II}-\mathrm{NaCl}, \mathrm{Na}_{2} \mathrm{SO}_{4}, \mathrm{MgSO}_{4}, \mathrm{Mg}\left(\mathrm{HCO}_{3}\right)_{2}$ and $\mathrm{Ca}\left(\mathrm{HCO}_{3}\right)_{2}$ & $8 \%$ & $\begin{array}{l}\mathrm{HCO}_{3}^{-}>\mathrm{Cl}^{-}>\mathrm{SO}_{4}, \mathrm{Cl}^{-}>\mathrm{HCO}_{3}^{-}>\mathrm{SO}_{4}^{2-} \text { and } \\
\mathrm{Cl}^{-}>\mathrm{SO}_{4}^{2-}>\mathrm{HCO}_{3}^{-}\end{array}$ \\
\hline III-NaCl, $\mathrm{Na}_{2} \mathrm{SO}_{4}, \mathrm{MgSO}_{4}, \mathrm{CaSO}_{4}$ and $\mathrm{Ca}\left(\mathrm{HCO}_{3}\right)_{2}$ & $12 \%$ & $\begin{array}{l}\mathrm{SO}_{4}>\mathrm{HCO}_{3}^{-}>\mathrm{Cl}^{-}, \mathrm{SO}_{4}>\mathrm{Cl}^{-}>\mathrm{HCO}_{3}^{-} \text {and } \\
\mathrm{Cl}^{-}>\mathrm{SO}_{4}^{2-}>\mathrm{HCO}_{3}^{-}\end{array}$ \\
\hline IV-NaCl, $\mathrm{MgCl}_{2}, \mathrm{MgSO}_{4}, \mathrm{Mg}\left(\mathrm{HCO}_{3}\right)_{2}$ and $\mathrm{Ca}\left(\mathrm{HCO}_{3}\right)_{2}$ & $19 \%$ & $\mathrm{HCO}_{3}{ }^{-}>\mathrm{Cl}^{-}>\mathrm{SO}_{4}{ }^{2-}$ and $\mathrm{Cl}^{-}>\mathrm{HCO}_{3}^{-}>\mathrm{SO}_{4}{ }^{2-}$ \\
\hline $\mathrm{V}-\mathrm{NaCl}, \mathrm{MgCl}_{2}, \mathrm{MgSO}_{4}, \mathrm{CaSO}_{4}$ and $\mathrm{Ca}\left(\mathrm{HCO}_{3}\right)_{2}$ & $31 \%$ & $\begin{array}{l}\mathrm{HCO}_{3}^{-}>\mathrm{Cl}^{-}>\mathrm{SO}_{4}{ }^{2-}, \mathrm{Cl}^{-}>\mathrm{HCO}_{3}^{-}>\mathrm{SO}_{4}{ }^{2-} \text { and } \\
\mathrm{Cl}^{-}>\mathrm{SO}_{4}{ }^{2-}>\mathrm{HCO}_{3}{ }^{-}\end{array}$ \\
\hline $\mathrm{VI}-\mathrm{NaCl}, \mathrm{MgCl}_{2}, \mathrm{CaCl}_{2}, \mathrm{CaSO}_{4}$ and $\mathrm{Ca}\left(\mathrm{HCO}_{3}\right)_{2}$ & $12 \%$ & $\mathrm{Cl}^{-}>\mathrm{HCO}_{3}^{-}>\mathrm{SO}_{4}{ }^{2-}$ and $\mathrm{Cl}^{-}>\mathrm{SO}_{4}{ }^{2-}>\mathrm{HCO}_{3}^{-}$ \\
\hline
\end{tabular}

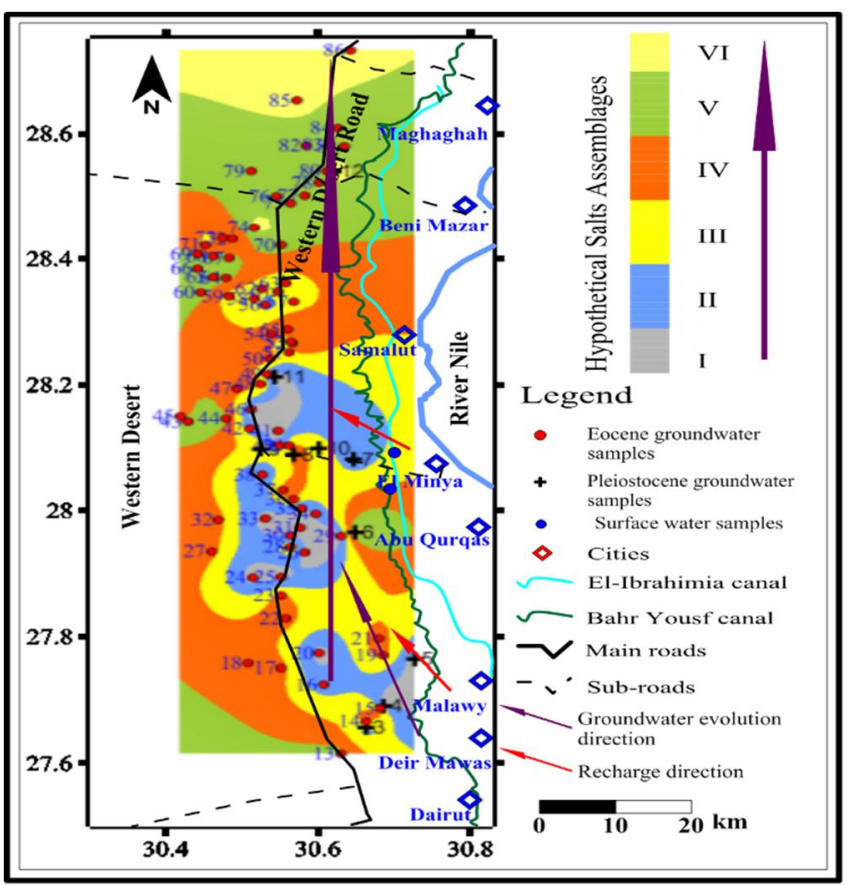

Fig. 10: The hypothetical salts assemblages distribution map of the Eocene groundwater in the study area 
Noteworthy mentioning that, $31 \%$ of the Eocene groundwater samples are characterized by the assemblages of hypothetical salts combination (V), regardless of their total salinities. This assemblage (V) contains two chloride salts, two sulfate salts and one bicarbonate salt, reflecting the effect of leaching and dissolution processes of marine salts (marine facies groundwater).

Finally, $20 \%$ and $12 \%$ of the groundwater samples of the Pleistocene and Eocene aquifers, respectively, are characterized by the assemblage of hypothetical salts combination (VI), regardless of their total salinities. The assemblage VI (three chloride salts) reflects the effect of marine salt combinations (marine facies groundwater) with some contribution of cation- exchange phenomena; this is confirmed by the presence of the $\mathrm{CaCl}_{2}$ salt. As in Fig.10, it is shown that the assemblage VI is existing in the groundwater at north of Beni-Mazar locality due to the existence of shale sheets where the cation exchange phenomena occurred on the surface of these shale sheets.

The direction of groundwater evolution $(\mathrm{I} \rightarrow \mathrm{VI})$ is from south to north direction in the same direction of the general groundwater flow (Fig.10). Assemblage (I and II) represents an earlier and less advanced stages of chemical development than that of assemblage (III). Also, assemblages I and II (three and two bicarbonate salts, respectively) reflect the dilution effect of surface water system (irrigation canals) on the groundwater, while assemblage III characterizes groundwater affected by the leaching and dissolution processes of the terrestrial salts.

There is a progress in the chemical development is noticed in the groundwater that dominated by the assemblages I and II (earlier and less stages of chemical development, where three and two bicarbonate salts are recognized) to the groundwater that dominated by the assemblages IV, V and VI (more advanced stages of chemical development, where two and three chloride salts are found). The assemblage IV $\left(\mathrm{MgCl}_{2}\right.$ and $\mathrm{MgCa}\left(\mathrm{HCO}_{3}\right)_{2}$ salts) is considered as a transitional stages between continental and marine facies of groundwater. This indicates meteoric water origin influenced either by leaching of terrestrial salts or marine salts in these aquifers.

In general, from Fig.10, it was shown that, the groundwater samples having $\mathrm{NaHCO}_{3}$, $\mathrm{Mg}\left(\mathrm{HCO}_{3}\right)_{2}$ and $\mathrm{Ca}\left(\mathrm{HCO}_{3}\right)_{2}$ salts represent an initial stage of mineralization (recharge area), while the groundwater samples that have the $\mathrm{Na}_{2} \mathrm{SO}_{4}, \mathrm{MgSO}_{4}$ and $\mathrm{CaSO}_{4}$ salts representing an intermediate stage of groundwater mineralization. On the other hand, the groundwater samples having $\mathrm{NaCl}$, $\mathrm{MgCl}_{2}$ and $\mathrm{CaCl}_{2}$ salts represent a more advanced stage of mineralization (discharge area or end point water). This trend of development indicates that the groundwater is subjected during its movement from the catchment (recharging) area to the discharge area to several changes of salt dissolution accompanied by ion exchange and metasomatism.

In conclusion, the groundwater of the Eocene fractured limestone aquifer is chemically, in the less and middle stages as well as more stage of evolution as its groundwater is a mixture of the other two sources (surface water and the Pleistocene aquifer). i.e., the Eocene aquifer is recharged directly from the surface water (due to seepage) and from the Pleistocene aquifer (due to the direct hydraulic connection between the Pleistocene aquifer and the Eocene aquifer through faulting).

\section{Geochemical classification}

Different authors have proposed methods for the geochemical classification of groundwater on a genetic basis; from these methods is the trilinear plotting system (Piper's diagram, 1953) that based on the use of the anions and cations.

\section{Piper's trilinear diagram (1953):}

The geochemical evolution of groundwater can be investigated through plotting the concentrations of major cations and anions in the diagram of Piper (1953). By plotting of the analytical data for groundwater samples of the Eocene aquifer on Piper's diagram (Fig.11), revealed that;

1-Most of the Eocene groundwater samples (71\%) in the study area are located in the sub-area (7), which is dominated by alkalies and strong acids (primary salinity). Some groundwater samples $(16 \%)$ of the Eocene aquifer in the study area are located in the sub-area (9), where no one cationanion pair exceeds $50 \%$. I.e., the majority of the Eocene groundwater samples $(87 \%)$ at the study area is located in the sub-areas ( 7 and 9) and has marine forces mainly due to leaching and dissolution processes of carbonate deposits (marine environment). The trilinear diagram suggests that the majority $(87 \%)$ of the Eocene groundwater samples in the study area are of mixed origin of 
mineralization, where the main sources of recharge are the seepage from the upper aquifer (Pleistocene aquifer) and sub-surface runoff water. This stands in agreement with the ion dominance $\left(\mathrm{Cl}^{-}>\mathrm{SO}_{4}{ }^{2-}>\mathrm{HCO}_{3}^{-}\right)$and the hypothetical salts combinations assemblages (IV, $\mathrm{V}$ and $\left.\mathrm{VI}\right)$, this means that these groundwater have the advanced stage.

2-Some groundwater samples of the Eocene aquifer (12\%) in the study area are located in the subarea (5), where carbonate hardness (secondary alkalinity) is dominated by alkaline earths and weak acid $\left[\mathrm{CaMg}\left(\mathrm{HCO}_{3}\right)_{2}\right]$. The trilinear diagram suggests that these groundwater samples $(12 \%)$ of the Eocene aquifer in the study area are of mixed origin of mineralization, where the main sources are the irrigation canals water and sub-surface runoff water as well as the seepage from the upper aquifer (Pleistocene aquifer). This stands in agreement with the ion dominance $\left(\mathrm{Cl}^{-}>\mathrm{HCO}_{3}{ }^{-}>\mathrm{SO}_{4}{ }^{2-}\right.$ and $\mathrm{Cl}^{-}>\mathrm{SO}_{4}{ }^{2-}>\mathrm{HCO}_{3}{ }^{-}$) and hydrochemical salts combinations assemblages (I, II, III and IV).

Noteworthy to mention that the presence of $12 \%$ of the Eocene groundwater samples and the irrigation canals water samples in the sub-area (5) reflects the irrigation canals being one of the recharging sources for the Eocene aquifer at some localities in the study area.

3 -Only $1 \%$ of the Eocene groundwater samples are lying in the sub-area (6), where non-carbonate hardness [secondary salinity, $\mathrm{CaMg}\left(\mathrm{SO}_{4}+\mathrm{Cl}\right)$ ] exceeds $50 \%$.

From the Piper's diagram (Fig.11), it was found that $50 \%$ of groundwater samples of the Eocene aquifer are located around the Pleistocene groundwater samples (selected samples), which reflects that there is a recharge from the Pleistocene aquifer to the Eocene aquifer at some localities in the study area. Also, this indicates that there is a hydraulic connection between the two aquifers at some localities through the faults plains.

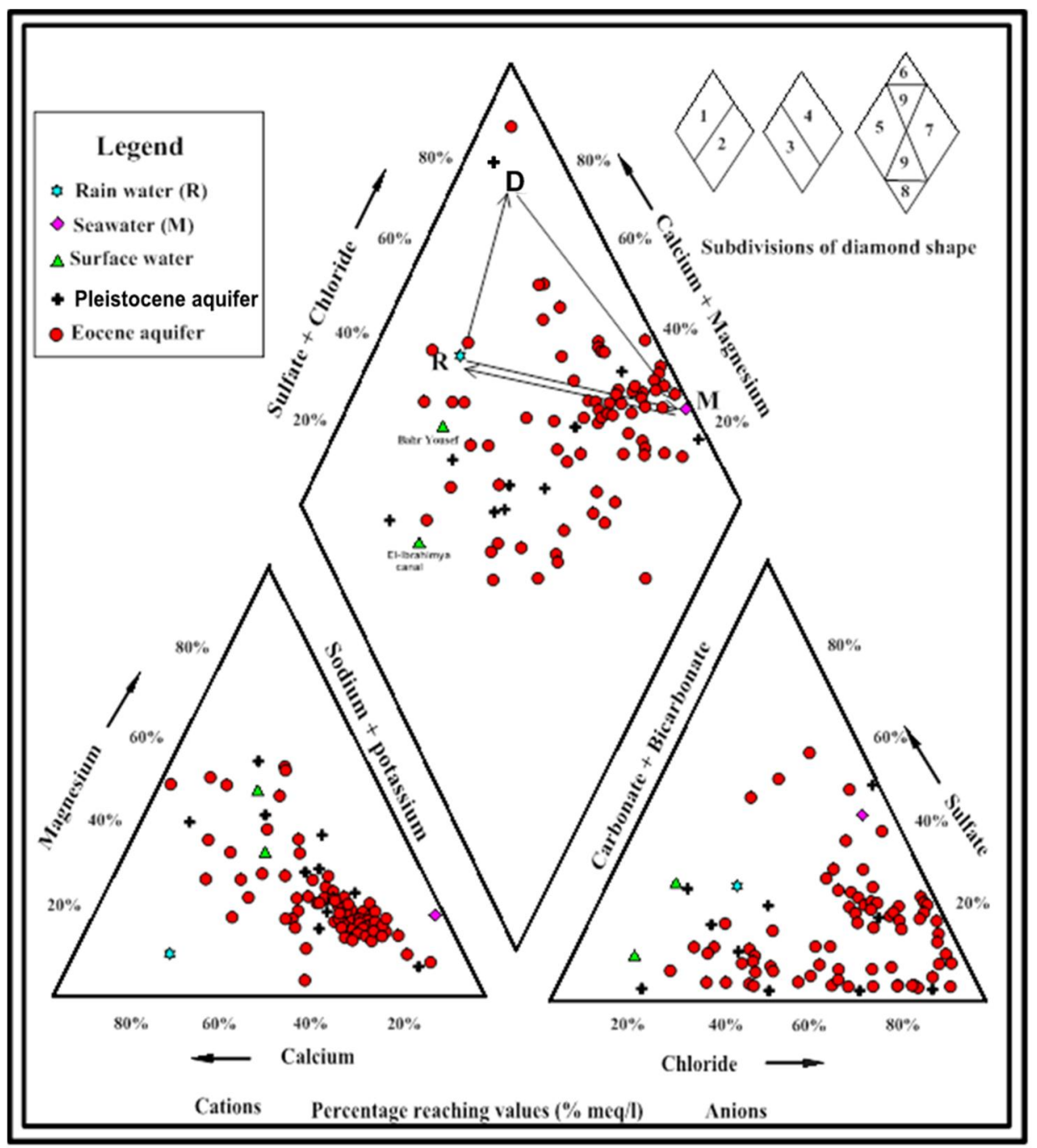

Fig. 11: Piper's and, Back and Hanshow's evolution diagram of the Eocene groundwater in the study area 
According to Back and Hanshow's (1979), some of the Eocene groundwater samples (23\%) and Pleistocene aquifer (one sample of the selected samples) undergo down-gradient movement, dissolution of gypsum, and marine salts $(\mathrm{R} \rightarrow \mathrm{D} \rightarrow \mathrm{M}$, encroachment and dolomitization). In addition to pathway reaction $M$ (marine facies water) $\rightarrow R$ (recharge area), flushing took place in few groundwater samples of Eocene aquifer. Thus, such groundwater of Eocene aquifer displays two reactions pathways for evolution to continental and marine facies water as a result of leaching and dissolution of terrestrial and marine salts besides flushing by fresh water.

In general, from Piper's trilinear and Back and Hanshow's diagram (Fig.11), it is obvious that; the groundwater samples of the Eocene aquifer and the selected groundwater samples of the Pleistocene aquifer have the same behavior which confirms the chemical similarity and also the hydraulic connection between the two aquifers through the faults plains.

\section{Geochemical modeling (Saturation indices):}

Some modeling software such as NETPATH (Plummer et al., 1994) was used for calculating the saturation indices of some relevant minerals to determine their affinity for dissolution or precipitation processes.

Calculation of mineral saturation index (SI) is a convenient method of representing the equilibrium condition of a solution with respect to a mineral.

Saturation index $(\mathrm{SI})=\log \mathrm{IAP} / \mathrm{K}_{\text {mineral }}$

The saturation indices values were used to identify thermodynamic that control groundwater composition, which describe the saturation of minerals in the aquifer, i.e., the saturation index is a useful quantity to determine whether the water is saturated, under-saturated, or supersaturated with respect to the given mineral. These values were calculated by using NETPATH (Plummer et al., 1994), where the positive value of SI (SI > 1; over-saturated) for specific mineral mean that the solution is saturated with this specific mineral leading to precipitation processes occurred, while the negative value of SI (SI $<1$, under-saturated) reflects that the dissolution processes occurred, and zero value of SI $(\mathrm{SI}=0)$ reflects that the mineral is in an equilibrium state with a solution. Noteworthy to mention that, $\mathrm{K}$ is the solubility product, which defines as solubility constant while IAP is the ion activation product, and both of K and IAP calculated by the law of mass action (Apello and Postma, 2005).

The calculation of saturation indices (Table 4) gives an understanding that most of the Eocene groundwater samples $(89 \%$ and $79 \%)$ are unsaturated with respect to aragonite and calcite, respectively (Figs. 12, 13 and 17), while $11 \%$ and $21 \%$ of the groundwater samples are saturated with respect to aragonite and calcite, respectively. Also, all samples are still in under-saturated condition with respect to gypsum, anhydrite and halite (Figs. 14, 15, 16 and 17). The saturation of some groundwater samples with some minerals is in the order calcite > aragonite; this is due to the composition of the plateau and the water bearing formation.

Highest concentration levels of calcium and bicarbonate in some samples are most likely as a result of dissolution processes of shell debris present in clayey layers. Moreover, the combination of dissolution processes producing enhanced bicarbonate within the plume and combined with redox reactions acquires bicarbonate complicate of the top of the plume (Jankowski and Acworth, 1997).

Aragonite and calcite are important contributors to the $\mathrm{Ca}^{2+}$ and $\mathrm{Mg}^{2+}$ levels in the groundwater through the basin has variable $\mathrm{Mg} / \mathrm{Ca}$ molar ratios, mostly between 1:1 and 5:1 (for the groundwater in the study area, the $\mathrm{Mg}^{2+} / \mathrm{Ca}^{2+}$ molar ratio ranges between $1: 1$ and 13:1), reflecting the multiple processes affecting the geochemistry of groundwater, such as possible mafic mineral dissolution, calcite precipitation, and cation exchange (Gates et al., 2008 and Yang et al., 2011).

Higher $\mathrm{Mg}^{2+} / \mathrm{Ca}^{2+}$ ratio (>2: 1) possibly indicates the high magnesium carbonate (Zhu et al., 2007). The consequence loss of $\mathrm{Ca}^{2+}$ in the groundwater is dissolution of small amounts of gypsum (Pacheco and Szocs, 2006).

The saturation indices for aragonite and calcite generally inversely correlated with TDS (Fig.17). Nearly the majority of water salinity $(<4000 \mathrm{mg} / \mathrm{l})$ is in under-saturated to saturate with respect to both minerals. It is attributed to carbonate minerals could be a controlling concentration of calcium, magnesium, and bicarbonate in the aquifer system water. 
The law of water salinity is more able to dissolve the limestone sediments that high water salinity, i.e., by increasing TDS, the saturation index shifts to under-saturated with respect to both minerals (Figs.12 and 13), in addition to the agricultural wastewater shares in the chemistry of the environment.

\section{In Conclusion,}

1. Most of the Eocene groundwater samples are under-saturated with calcite. This means that these carbonate mineral phases may have dissolved in the Eocene aquifer environment and the groundwater is able to dissolve additional amounts of calcite, this may be due to the continuous recharge from the surface water (El-Ibrahimia and Bahr Yousf canals).

2. All groundwater samples of the Eocene aquifer are under-saturated with respect to the halite, anhydrite and gypsum, which means that the Eocene groundwater in the study area can dissolve extra amounts of these mineral phases.

Table 4. The saturation indices for the Eocene groundwater samples in west El-Minya area

\begin{tabular}{|c|c|c|c|c|c|}
\hline Sample No. & $\begin{array}{l}\text { Halite } \\
\mathrm{Na} / \mathrm{Cl}\end{array}$ & $\begin{array}{l}\text { Calcite } \\
\mathrm{CaCO}_{3}\end{array}$ & $\begin{array}{c}\text { Aragonite } \\
\mathrm{CaCO}_{3}\end{array}$ & $\begin{array}{c}\text { Gypsum } \\
\text { CaSO }_{4.2 \mathrm{H}_{2} \mathrm{O}}\end{array}$ & $\begin{array}{c}\text { Anhydrite } \\
\mathrm{CaSO}_{4}\end{array}$ \\
\hline 13 & -5.311 & -0.289 & -0.433 & -1.998 & -2.218 \\
\hline 14 & -2.979 & 0.011 & -0.133 & -3.103 & -3.322 \\
\hline 15 & -3.868 & -0.066 & -0.210 & -2.847 & -3.067 \\
\hline 16 & -5.193 & -0.097 & -0.241 & -2.246 & -2.466 \\
\hline 17 & -4.174 & -0.037 & -0.180 & -1.954 & -2.174 \\
\hline 18 & -4.870 & 0.052 & -0.091 & -1.950 & -2.170 \\
\hline 19 & -5.641 & -0.321 & -0.464 & -2.357 & -2.577 \\
\hline 20 & -5.111 & -0.082 & -0.226 & -2.550 & -2.770 \\
\hline 21 & -4.249 & -0.078 & -0.222 & -2.204 & -2.424 \\
\hline 22 & -4.914 & 0.072 & -0.072 & -2.109 & -2.233 \\
\hline 23 & -5.154 & 0.016 & -0.128 & -1.744 & -1.964 \\
\hline 24 & -4.961 & -0.229 & -0.373 & -2.397 & -2.617 \\
\hline 25 & -4.326 & -0.256 & -0.400 & -2.423 & -2.643 \\
\hline 26 & -4.914 & -0.224 & -0.368 & -3.007 & -3.227 \\
\hline 27 & -3.854 & -0.122 & -0.266 & -2.120 & -2.339 \\
\hline 28 & -3.141 & -0.390 & -0.534 & -3.060 & -3.280 \\
\hline 29 & -4.282 & -0.017 & -0.161 & -2.455 & -2.675 \\
\hline 30 & -4.788 & -0.030 & -0.173 & -2.795 & -3.015 \\
\hline 31 & -4.084 & -0.003 & -0.147 & -2.768 & -2.988 \\
\hline 32 & -4.156 & -0.040 & -0.184 & -2.252 & -2.472 \\
\hline 33 & -4.399 & -0.076 & -0.220 & -2.833 & -3.053 \\
\hline 34 & -4.776 & 0.038 & -0.106 & -2.575 & -2.795 \\
\hline 35 & -3.671 & 0.065 & -0.079 & -2.676 & -2.896 \\
\hline 36 & -2.956 & 0.309 & 0.166 & -2.346 & -2.566 \\
\hline 37 & -5.213 & 0.241 & 0.097 & -2.101 & -2.321 \\
\hline 38 & -4.465 & 0.292 & 0.148 & -2.938 & -3.158 \\
\hline 39 & -3.645 & 0.105 & -0.039 & -3.374 & -3.594 \\
\hline 40 & -2.839 & 0.155 & 0.011 & -3.019 & -3.238 \\
\hline 41 & -3.033 & 0.428 & 0.285 & -2.875 & -3.094 \\
\hline 42 & -4.325 & -1.132 & -1.275 & -2.150 & -2.370 \\
\hline 43 & -3.853 & -0.169 & -0.313 & -1.179 & -1.399 \\
\hline 44 & -4.361 & -0.108 & -0.252 & -1.263 & -1.482 \\
\hline 45 & -2.131 & 0.499 & 0.355 & -0.216 & -0.433 \\
\hline 46 & -3.420 & -0.403 & -0.546 & -2.326 & -2.546 \\
\hline 47 & -4.219 & 0.145 & 0.001 & -2.417 & -2.637 \\
\hline 48 & -3.852 & 0.644 & 0.501 & -2.928 & -3.147 \\
\hline 49 & -3.808 & 0.110 & -0.034 & -2.121 & -2.341 \\
\hline 50 & -4.779 & 0.047 & -0.097 & -2.152 & -2.372 \\
\hline 51 & -3.069 & -0.970 & -1.114 & -0.914 & -1.133 \\
\hline 52 & -2.432 & -0.312 & -0.455 & -0.674 & -0.893 \\
\hline 53 & -3.985 & -0.434 & -0.578 & -1.917 & -2.137 \\
\hline 54 & -4.152 & -0.155 & -0.299 & -2.030 & -2.250 \\
\hline
\end{tabular}


Cont. Table 4

\begin{tabular}{|c|c|c|c|c|c|}
\hline Sample No. & $\begin{array}{l}\text { Halite } \\
\mathrm{Na} / \mathrm{Cl}\end{array}$ & $\begin{array}{l}\text { Calcite } \\
\mathrm{CaCO}_{3}\end{array}$ & $\begin{array}{c}\text { Aragonite } \\
\mathrm{CaCO}_{3}\end{array}$ & $\begin{array}{c}\text { Gypsum } \\
\mathrm{CaSO}_{4.2 \mathrm{H}_{2} \mathrm{O}}\end{array}$ & $\begin{array}{c}\text { Anhydrite } \\
\mathrm{CaSO}_{4}\end{array}$ \\
\hline 55 & -3.869 & -0.566 & -0.700 & -1.565 & -1.785 \\
\hline 56 & -3.438 & -0.523 & -0.667 & -1.734 & -1.954 \\
\hline 57 & -4.068 & -0.429 & -0.573 & -0.879 & -1.098 \\
\hline 58 & -3.770 & -0.358 & -0.502 & -1.198 & -1.418 \\
\hline 59 & -4.007 & 0.011 & -0.133 & -1.451 & -1.670 \\
\hline 60 & -3.396 & -0.329 & -0.473 & -1.424 & -1.644 \\
\hline 61 & -3.061 & -0.409 & -0.553 & -1.004 & -1.223 \\
\hline 62 & -4.778 & -0.320 & -0.463 & -1.317 & -1.537 \\
\hline 63 & -4.479 & -0.204 & -0.348 & -1.203 & -1.423 \\
\hline 64 & -3.963 & -0.117 & -0.261 & -1.622 & -1.842 \\
\hline 65 & -4.075 & -0.137 & -0.280 & -1.533 & -1.753 \\
\hline 66 & -3.966 & -0.729 & -0.873 & -1.585 & -1.805 \\
\hline 67 & -3.591 & -0.129 & -0.273 & -1.448 & -1.668 \\
\hline 68 & -3.535 & -0.313 & -0.457 & -1.453 & -1.673 \\
\hline 69 & -3.793 & -0.127 & -0.271 & -1.486 & -1.705 \\
\hline 70 & -3.239 & -0.155 & -0.299 & -1.340 & -1.559 \\
\hline 71 & -3.804 & -0.333 & -0.477 & -1.489 & -1.709 \\
\hline 72 & -3.525 & -0.252 & -0.396 & -1.422 & -1.642 \\
\hline 73 & -3.638 & -0.049 & -0.193 & -1.745 & -1.965 \\
\hline 74 & -2.501 & -0.110 & -0.253 & -1.089 & -1.307 \\
\hline 75 & -3.529 & -0.152 & -0.296 & -1.515 & -1.734 \\
\hline 76 & -3.887 & -0.318 & -0.462 & -1.316 & -1.536 \\
\hline 77 & -3.105 & -0.216 & -0.360 & -1.168 & -1.388 \\
\hline 78 & -3.224 & -0.132 & -0.276 & -1.299 & -1.519 \\
\hline 79 & -2.646 & -0.274 & -0.418 & -1.590 & -1.808 \\
\hline 80 & -2.622 & -0.050 & -0.149 & -1.062 & -1.281 \\
\hline 81 & -2.455 & -0.158 & -0.302 & -0.896 & -1.114 \\
\hline 82 & -2.174 & -0.152 & -0.296 & -0.910 & -1.128 \\
\hline 83 & -2.980 & -0.037 & -0.181 & -1.947 & -2.166 \\
\hline 84 & -1.917 & -0.172 & -0.316 & -0.658 & -0.875 \\
\hline 85 & -2.585 & -0.146 & -0.290 & -1.346 & -1.565 \\
\hline 86 & -2.428 & -0.169 & -0.313 & -1.230 & -1.448 \\
\hline
\end{tabular}




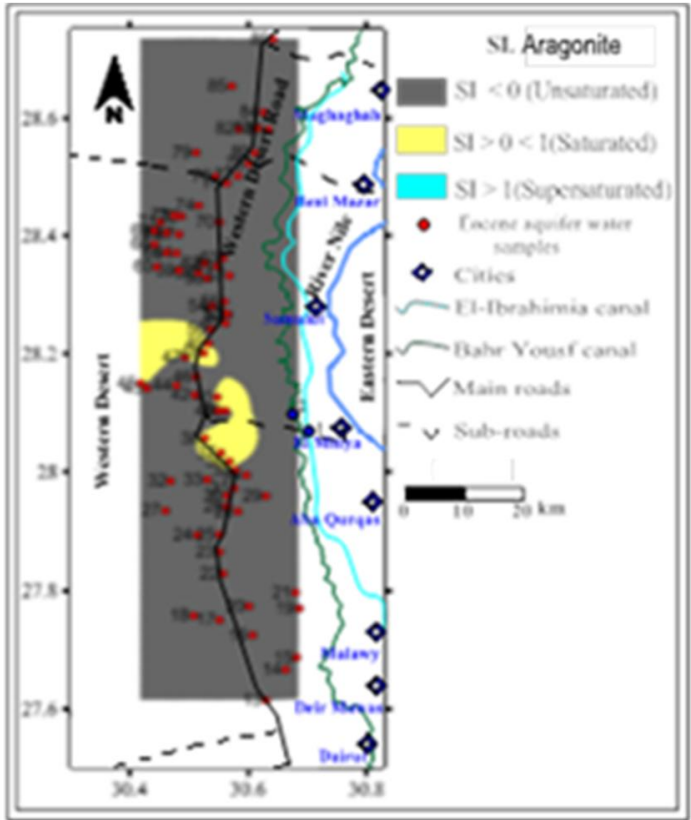

Fig.12. Saturation index of the aragonite mineral in the Eocene groundwater at the study area

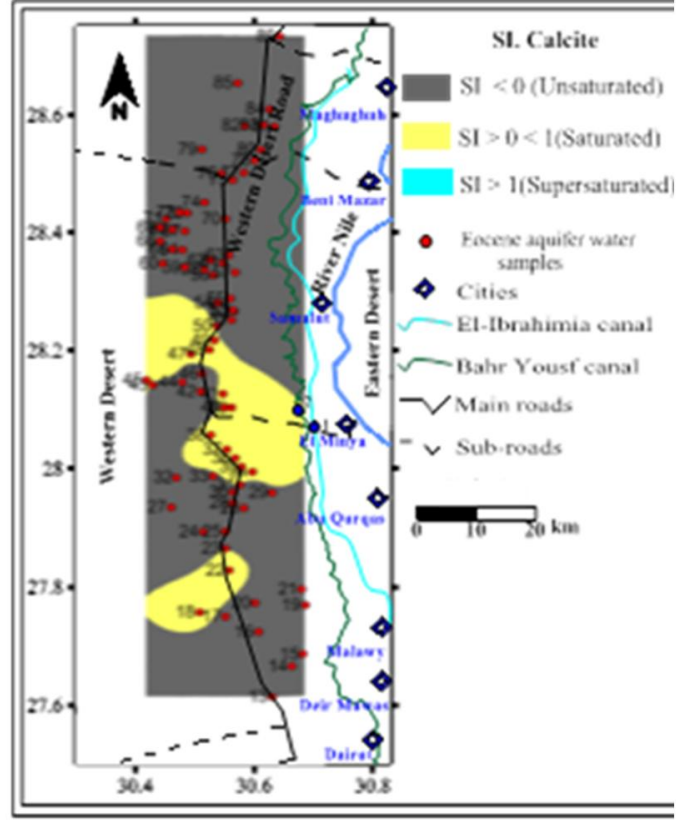

Fig.13. Saturation index of the calcite mine in the Eocene groundwater at the study area

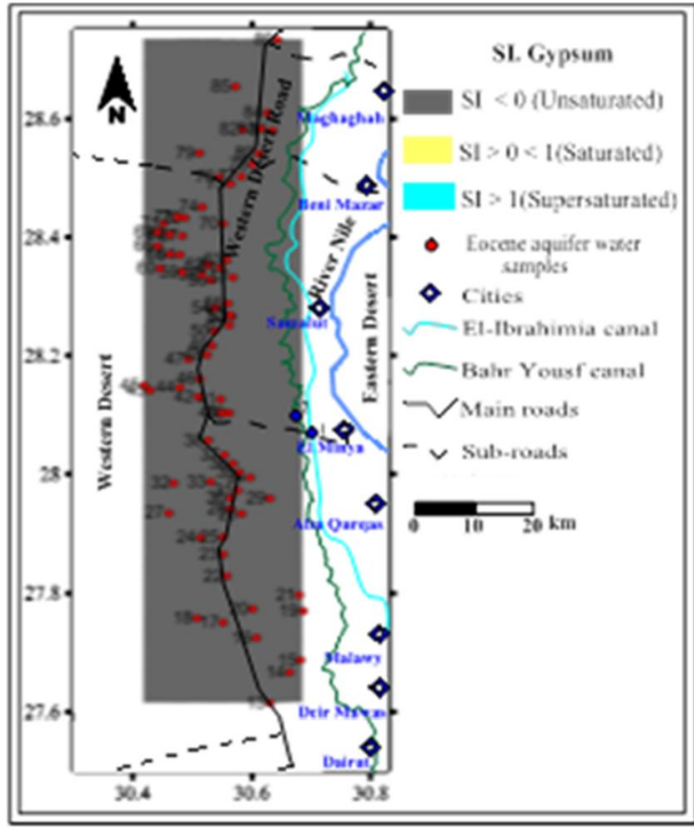

Fig.14. Saturation index of the gypsum mineral in the Eocene groundwater at the study area 


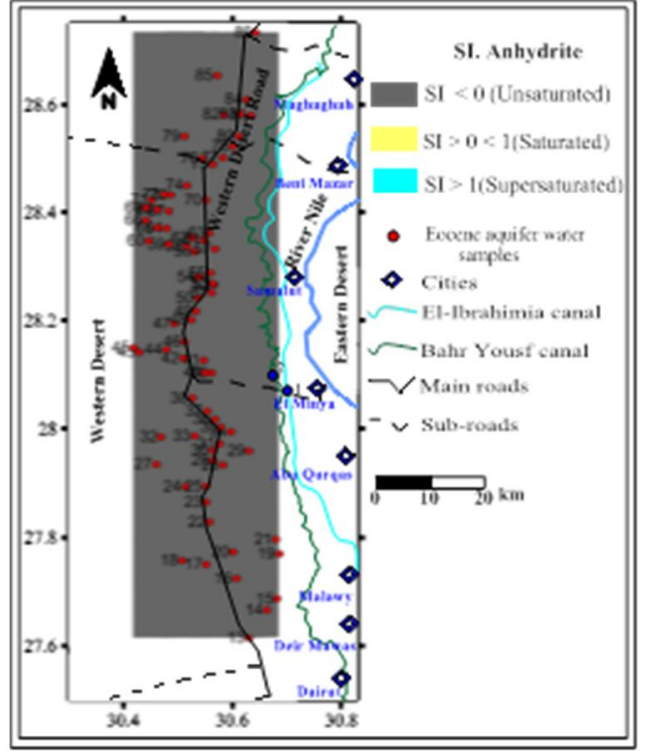

Fig.15. Saturation index of the anhydrite mineral in the Eocene groundwater at the study area

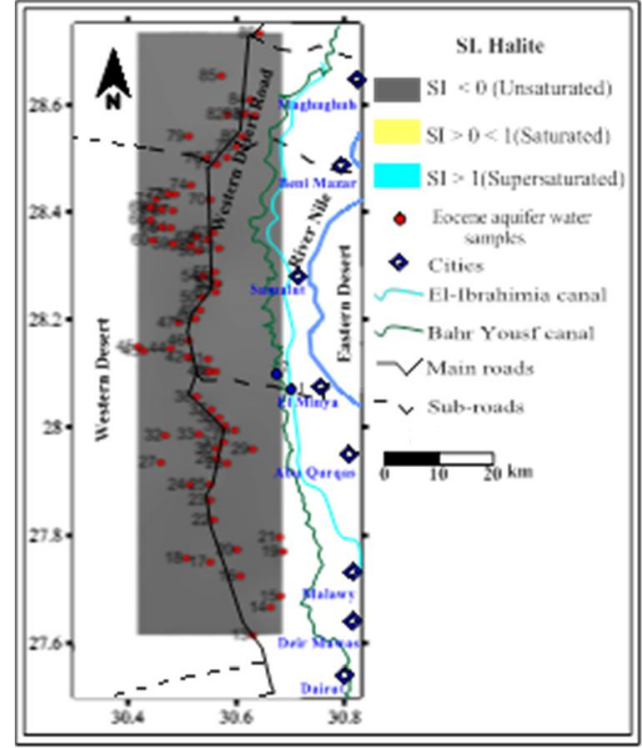

Fig.16. Saturation index of the halite mineral in the Eocene groundwater at the study area

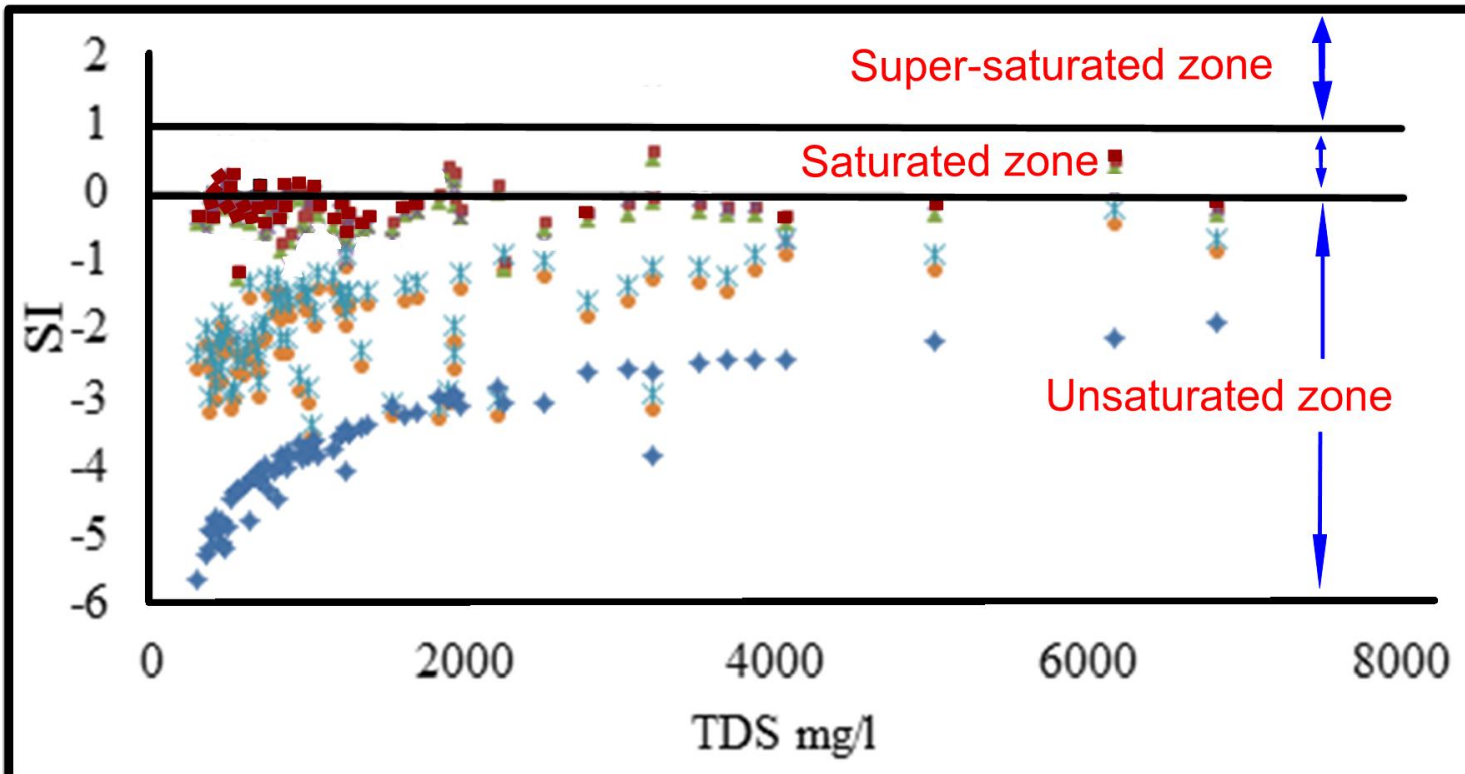

- Anhydrite $\triangle$ Aragonite - Calcite $\times$ Gypsum $\bullet$ Halite

Fig.17: Saturation indices outputs of the Eocene groundwater in the study area

\section{Statistical analyses (cluster analysis)}

The cluster analysis (CA) technique is used to classify the examined parameters of groundwater into categories or clusters based on their similarities or dissimilarities in the variation of the data sets using hierarchical cluster analysis (HCA). The degree of association between two objects is maximal if they belong to the same group and minimal otherwise. In hierarchical cluster analysis, the distance between samples is used as a measure of similarity (Vega et al., 1998). One of the main purposes of cluster analysis in the study area is to identify samples affected by agricultural activities and seepage from the surface water system (El-Ibrahimia and Bahr Yousf canals), as well as the recharge from the overlying aquifer (Pleistocene aquifer). The results of the cluster analysis (Dendogram) for the samples are represented in figures Nos.18 and 19. The CA grouped 74 sampling locations into 3 
clusters named as 1, 2 and 3. Clusters of the samples are listed in table (5), which indicates that each cluster has a water quality of its own, which is different from the other clusters, with all the points falling along a straight line joining the highly saline water at one end and the clusters of fresh water points at the other end.

Cluster No.1 is represented by 63 groundwater samples tapping the Eocene aquifer and eight groundwater samples (guidance samples) tapping the Pleistocene aquifer as well as two surface water samples representing El-Ibrahimia and Bahr Yousf canals (Table 5). This cluster is subdivided into three sub-clusters (A, B and C) that contain 44, 10 and 9 groundwater samples, respectively (Table 5). The groundwater samples in sub-cluster No.1 are distributed all over the study area. They are characterized by salinities varying between fresh water $(294 \mathrm{mg} / \mathrm{l})$ and brackish water $(2517 \mathrm{mg} / \mathrm{l})$, with the anion dominance, $\mathrm{Cl}^{-}>\mathrm{SO}_{4}{ }^{2-}>\mathrm{HCO}_{3}{ }^{-}$and cation dominance, $\mathrm{Na}^{+}>\mathrm{Mg}^{2+}>\mathrm{Ca}^{2+}$. The groundwater samples in this cluster are affected by direct recharge from the irrigation canals water (El-Ibrahimia and Bahr Yousf canals) as well as by the local seepage from the overlying Pleistocene aquifer.

Cluster No.2 is represented by eight groundwater samples tapping the Eocene aquifer and one groundwater sample (guidance sample) tapping the Pleistocene aquifer (Table 5). This cluster is subdivided into two sub-clusters (A and B) that contain eight and one groundwater samples, respectively (Table 5). The groundwater samples in this cluster are located to the north of the study area and they are characterized by higher salinities than the previous cluster, where the salinity is varying between 2785 and $4062 \mathrm{mg} / 1$, with the nion dominance, $\mathrm{Cl}^{-}>\mathrm{SO}_{4}{ }^{2-}>\mathrm{HCO}_{3}{ }^{-}$and cation dominance, $\mathrm{Na}^{+}>\mathrm{Mg}^{2+}>\mathrm{Ca}^{2+}$. This is mainly attributed to the over-pumping activity concerning the reclamation projects and the infiltration of return flow after irrigation through the shallow depths to the groundwater as well as high development and miss use of pesticides and fertilizers

Cluster No.3 is represented by 3 groundwater samples tapping the Eocene aquifer and one groundwater sample (guidance sample) tapping the Pleistocene aquifer, respectively (Table 5). It is subdivided into two sub-clusters (A and B) that contain 3 and 1 groundwater samples, respectively (Table 5). The groundwater samples in this cluster are located to the north of the study area and they are characterized by higher salinities than the previous clusters, where the salinity is varying between 5009 to $6816 \mathrm{mg} / \mathrm{l}$, with the anion dominance, $\mathrm{Cl}^{-}>\mathrm{SO}_{4}{ }^{2-}>\mathrm{HCO}_{3}{ }^{-}$and cation dominance, $\mathrm{Na}^{+}>\mathrm{Mg}^{2+}$ $>\mathrm{Ca}^{2+}$. This is attributed to the dissolution process of carbonate rocks during the subsurface flow of groundwater through cracks and joints or due to the carbonate materials transported from limestone plateau by weathering, as well as the presence of clay layers and marl intercalation in the succession of limestone (intercalation between shale and clay with the limestone layers) at north the study area.

It could be concluded that, there is a salinity gradient from cluster No. 1 to cluster No.3 in this sequence; cluster No. $3>$ cluster No. $2>$ cluster No.1. The statistical analyses confirm that there is a hydraulic connection between the Pleistocene and Eocene aquifers.

From Fig.18, at clusters Nos. 2 and 3, it was noticed that the Pleistocene groundwater samples Nos. 6 and 10 (guidance samples) are located in sub-clusters (B) and not located in the same subclusters (A) that contains the groundwater samples of the Eocene aquifer at the main clusters 2 and 3, respectively. This indicates that there is no strong connection between the Eocene and Pleistocene aquifers in these localities at the study area.

From Fig.19, it was shown that the majority of the Eocene groundwater samples (59\%) in the study area are affected by seepage from the surface water system (El-Ibrahimia and Bahr Yousf canals), as well as the recharge from the overlying aquifer (Pleistocene aquifer). While, $41 \%$ of the Eocene groundwater samples in the study area are affected by seepage from the irrigation canals (ElIbrahimia and Bahr Yousf canals) and the recharge that may be occurring at a distance can be reached to about $6 \mathrm{~km}$. 
Table 5: Cluster groups and their members of the surface water and groundwater samples in the study area

\begin{tabular}{|c|c|c|}
\hline $\begin{array}{l}\text { Cluster } \\
\text { group }\end{array}$ & Sub-clusters & Members (Sample No.) \\
\hline \multirow{3}{*}{1} & $\mathbf{A}$ & $\begin{array}{l}\text { El-Ibrahimia \& Bahr Yousf canals water samples and the Pleistocene groundwater } \\
\text { samples }(3,4,5,7,9 \text { and 11) as well as the Eocene groundwater samples }(64,66 \text {, } \\
65,55,59,44,21,54,17,53,62,63,69,71,76,43,73,58,27,49,35,39,15,19, \\
13,20,30,34,16,24,26,22,50,23,18,37,32,47,31,25,29,33,38 \text { and 42). }\end{array}$ \\
\hline & B & $\begin{array}{l}\text { Pleistocene groundwater sample (8) and the Eocene groundwater samples }(51,61 \text {, } \\
68,75,67,72,56,60,46 \text { and } 57) \text {. }\end{array}$ \\
\hline & $\mathbf{C}$ & $\begin{array}{l}\text { Pleistocene groundwater sample (12) and the Eocene groundwater samples (40, 41, } \\
70,78,28,14,36,83 \text { and } 77) \text {. }\end{array}$ \\
\hline \multirow{2}{*}{2} & $\mathbf{A}$ & Eocene groundwater samples $(79,85,80,52,81,74,86$ and 48$)$ \\
\hline & B & Pleistocene groundwater sample (6). \\
\hline \multirow{2}{*}{3} & $\mathbf{A}$ & Eocene groundwater samples $(45,84$ and 82$)$ \\
\hline & B & Pleistocene groundwater sample (10) \\
\hline
\end{tabular}

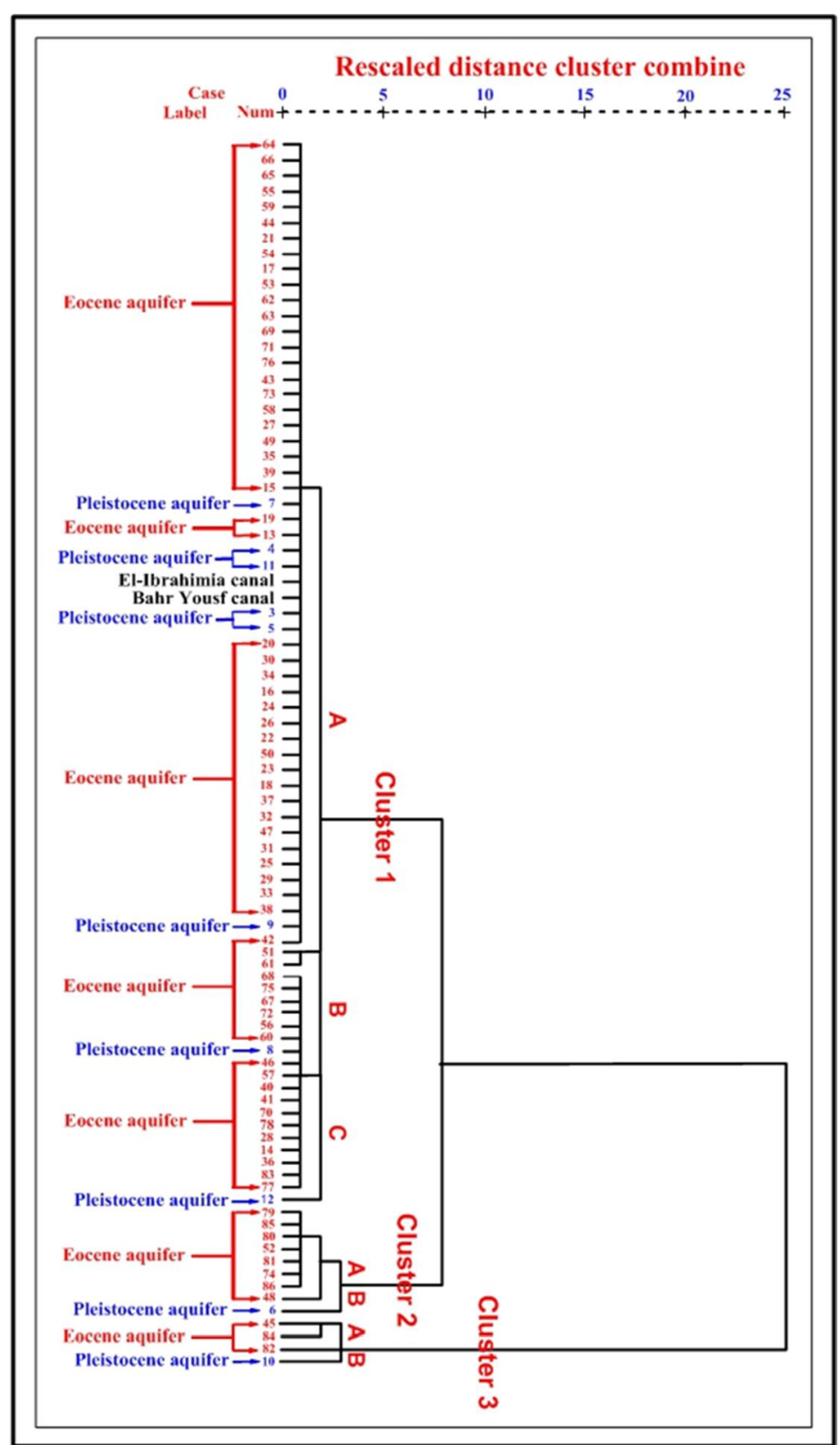

Fig.18: Dendogram of cluster analysis of both surface water and groundwater in the study area 


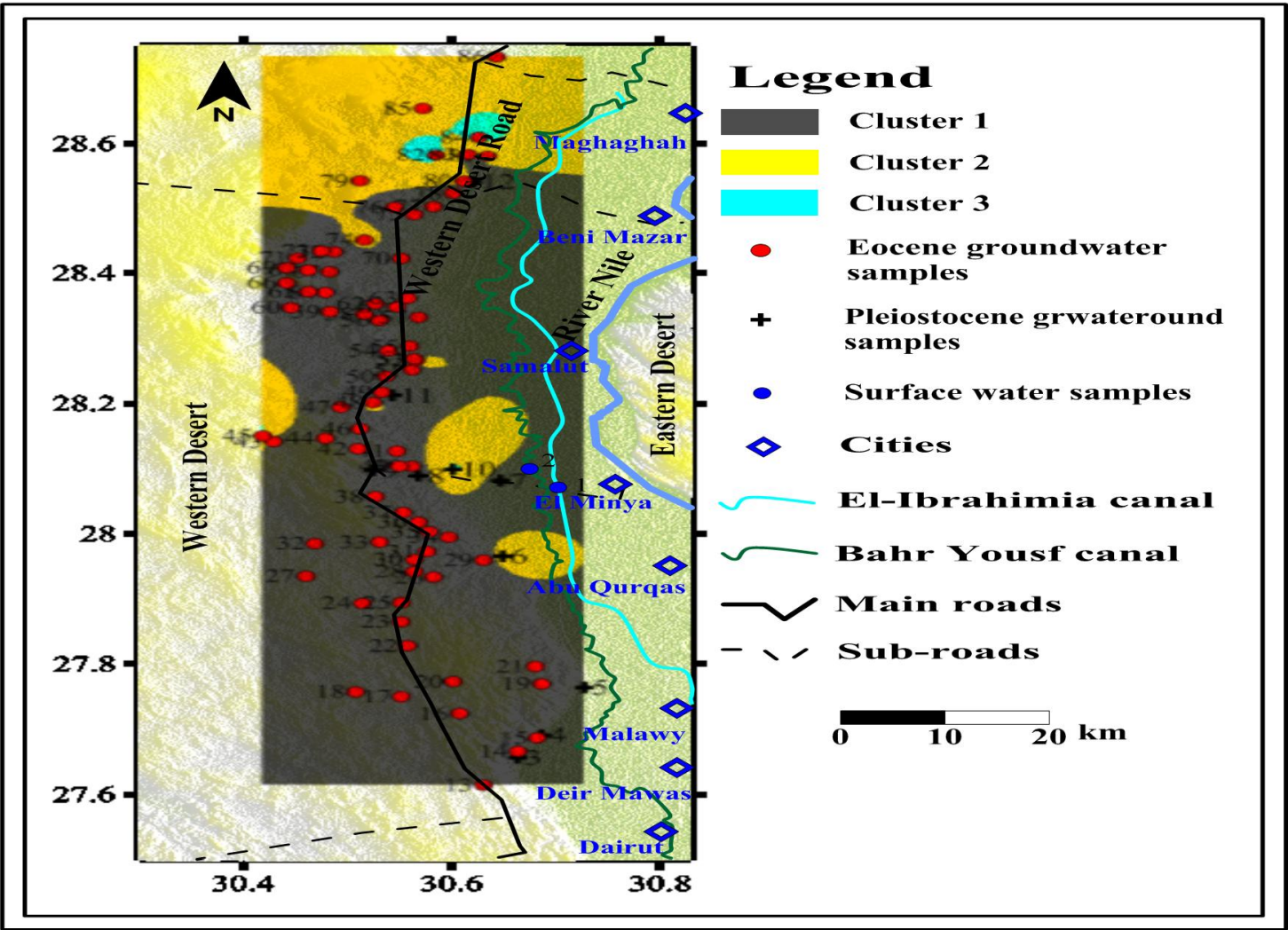

Fig. 19: The cluster distribution map of the Eocene groundwater in the study area

\section{Suitability of water resources in the study area for different purposes}

\section{I-Suitability of water resources for human drinking purpose}

The apt-ness of the inspected surface and groundwater in the study area for drinking purpose was determined by comparing its chemical composition (Table 1) with the World Health Organization standards for drinking water (WHO, 2011). It was clear that, El-Ibrahimia and Bahr Yousf canals samples and $70 \%$ of the Pleistocene groundwater samples (guidance samples) as well as $54 \%$ of the Eocene groundwater samples in the study area are suitable for drinking as they have TDS values less than the permissible limit of drinking water $(1000 \mathrm{mg} / \mathrm{l})$. On the other hand, the rest of the groundwater samples $(30 \%$ of the Pleistocene and $46 \%$ of the Eocene aquifers, respectively) are unsuitable for drinking as they have TDS more than the permissible limit of drinking water $(1000 \mathrm{mg} / \mathrm{l})$.

\section{II-Suitability of water resources for livestock, poultry and animals purpose}

Water involved in every aspect of poultry metabolism. For livestock and poultry, Mckee and Wolf (1963) which define the principals for evaluation according to the total dissolved solids (TDS). The groundwater of the studied area has been separated into four classes of quality for livestock and poultry consumption as follows:

1. Excellent groundwater (TDS $<1000 \mathrm{mg} / 1$ ), $70 \%$ of the Pleistocene groundwater samples (guidance samples) and $54 \%$ of the Eocene groundwater samples in the study area are excellent for livestock and poultry drinking as they have TDS values ranging from 294 to $986 \mathrm{mg} / \mathrm{l}$.

2. Very satisfactory groundwater (TDS $1000-3000 \mathrm{mg} / \mathrm{l}$ ), $10 \%$ of the Pleistocene groundwater samples (guidance samples) and $35 \%$ of the Eocene groundwater samples in the study area are very satisfactory for livestock and poultry drinking as they have TDS values ranging from 1000 to $2785 \mathrm{mg} / \mathrm{l}$.

3. Satisfactory groundwater (TDS $3000-5000 \mathrm{mg} / \mathrm{l}$ ), $10 \%$ of the Pleistocene groundwater samples (guidance samples) and $9 \%$ of the Eocene groundwater samples in the study area are satisfactory for livestock and poultry drinking as they have TDS values ranging from 3048 to $4062 \mathrm{mg} / 1$. 
4. Water can be used with reasonable safety for dairy and beef cattle, sheep, swine and horses, avoid use for pregnant or lactating animals, not acceptable for poultry (TDS $5000-7000 \mathrm{mg} / 1$ ), $10 \%$ of the Pleistocene groundwater samples (guidance samples) and $2 \%$ of the Eocene groundwater samples in the study area can be used with reasonable safety for dairy and beef cattle, sheep, swine and horses drinking as they have TDS values ranging from 5009 to $6816 \mathrm{mg} / \mathrm{l}$.

\section{III-Suitability of groundwater for irrigation purpose}

The evaluation of the Eocene groundwater in the study area for irrigation purposes depends on the classification of the U.S. Salinity Laboratory Staff's Classification (1954). It uses the relationship between sodium adsorption ratio (SAR) and electrical conductivity (EC). By applying this classification for the surface water and groundwater samples in the study area (Fig.20), it can be concluded that;

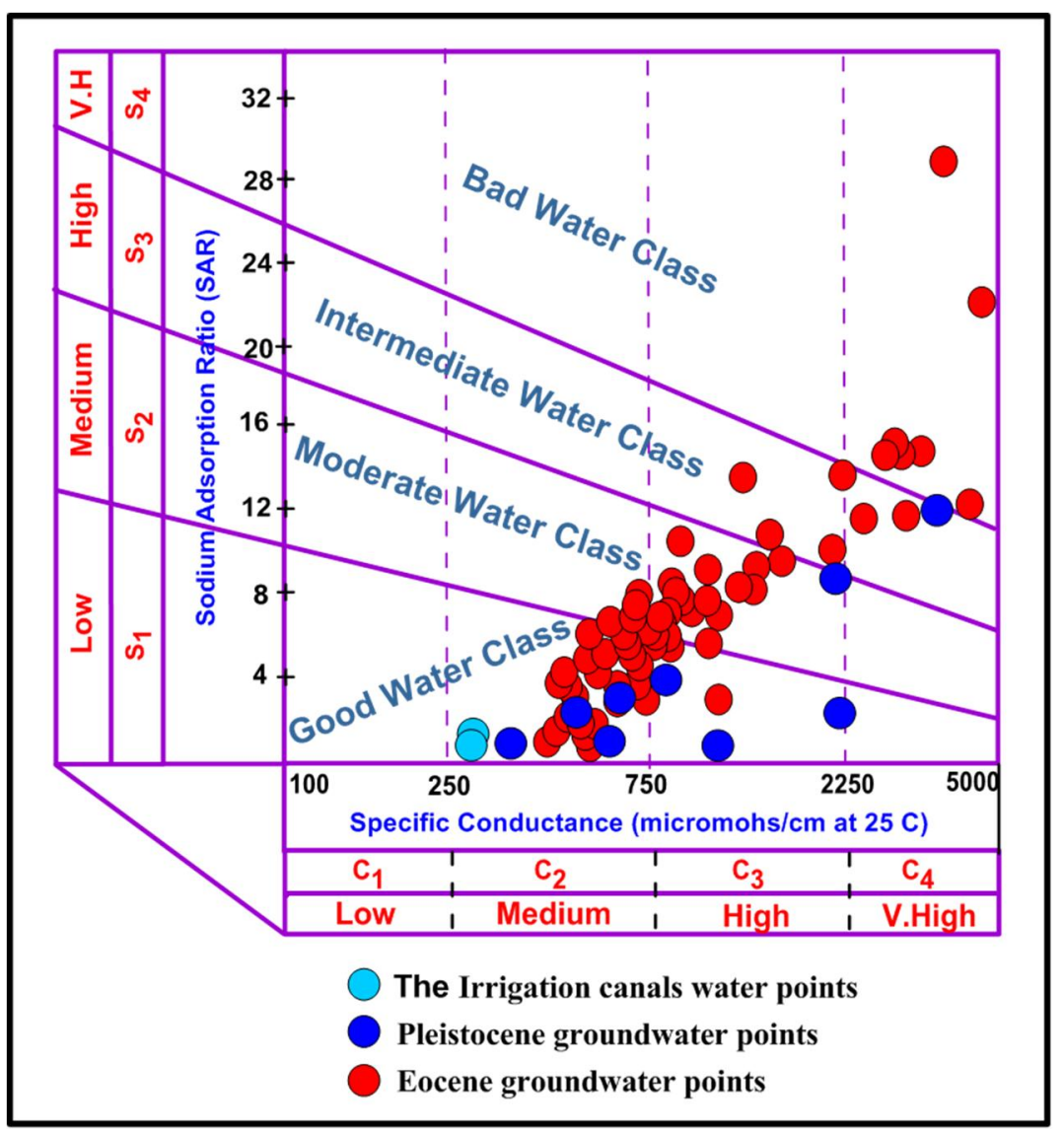

Fig.20: U.S. Salinity Laboratory Staff diagram for the irrigation canals water samples and Pleistocene as well as Eocene groundwater samples in west El-Minya area

All irrigation canals water samples and $70 \%$ of the Pleistocene groundwater samples (guidance samples) as well as $47 \%$ of the Eocene groundwater samples in the study area are suitable for irrigation of almost all soils under ordinary conditions, if a moderate amount of leaching processes occurs.

While, $20 \%$ and $10 \%$ of both the Eocene and Pleistocene groundwater samples in the study area, respectively, are suitable for irrigation under ordinary conditions, but requires special soil management with low leaching and plants with good salt tolerance.

Also, $9 \%$ and $10 \%$ of both the Eocene and Pleistocene groundwater samples in the study area, respectively, are suitable for irrigation under special conditions, where it requires special soil management, good drainage high Leaching and organic matter.

On the other hand, $9 \%$ of the Eocene groundwater samples are located in the bad water class as well as, the rest of the Eocene and Pleistocene groundwater samples (15\% and 10\%, respectively) are located out of the scale. So, they are unsuitable for irrigation under ordinary conditions, but may be 
used occasionally under special conditions as the soils must be permeable, and drainage must be adequate.

Finally, it can be concluded that the groundwater samples of the Eocene aquifer in the study area are arranged with respect to the water quality for irrigation in the following sequence; $47 \%$ of the groundwater samples are good water, $20 \%$ of the groundwater samples are moderate water, $9 \%$ of the groundwater samples are intermediate water and $24 \%$ of the groundwater samples are bad water (Fig.21).

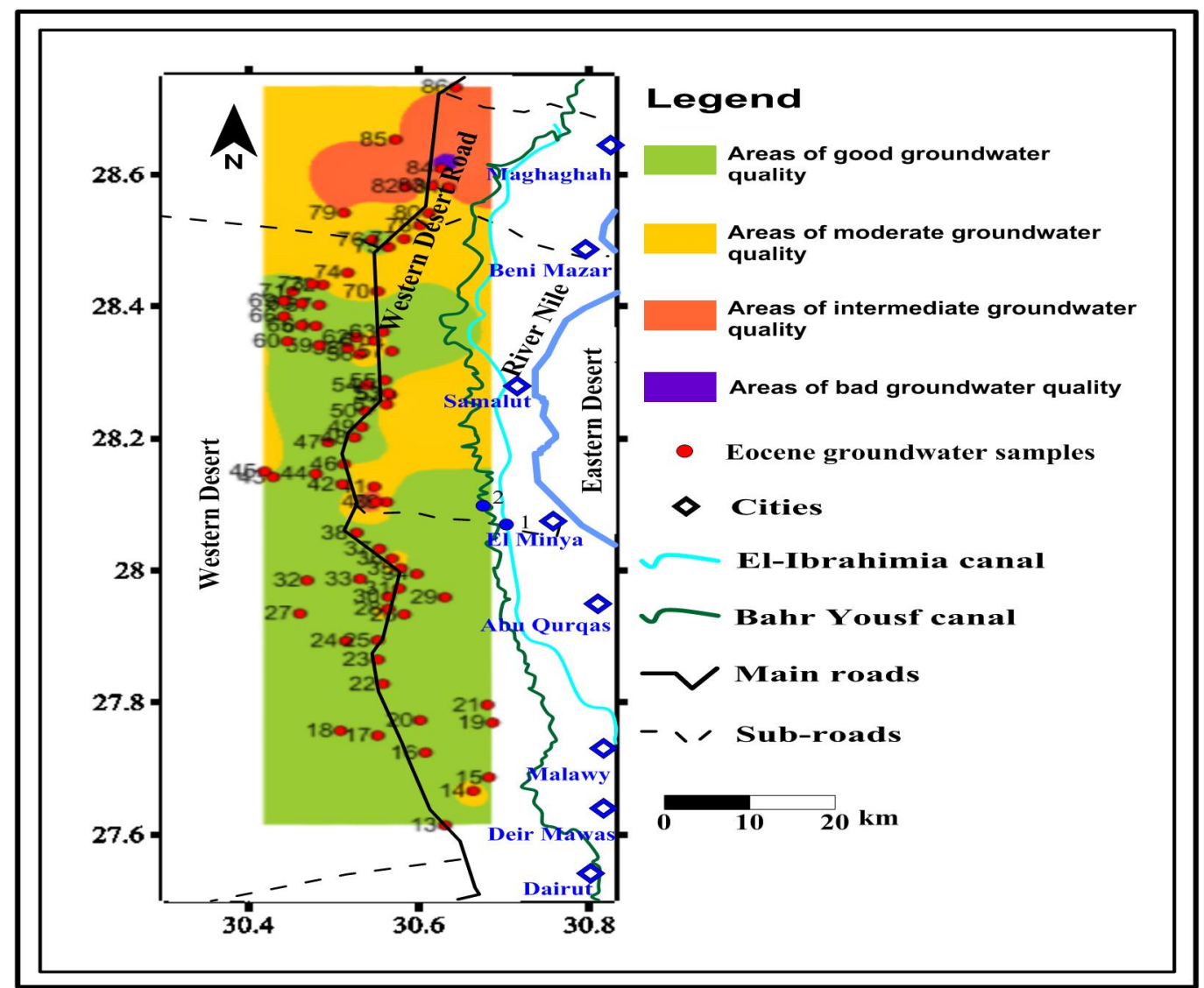

Fig. 21: The Eocene groundwater quality areas distribution map in west El-Minya governorate

\section{Conclusion}

The study area is characterized by three geomorphological units; the limestone plateau (tableland), old alluvial plain (River terraces) and recent alluvial plain.

Geologically, the surface of the study area is built of Pleistocene gravel and sand, and Eocene limestone occupying the area between the Nile River and the scarp of the plateau. The main structures in the study area are represented by fracturing and a number of faults trending in NW-SE direction, which play an important role in groundwater occurrences in the limestone and hence its capability to store and transmit groundwater.

Hydrogeologically, the Eocene fractured limestone aquifer is the good water bearing formation in the investigated area. Where the Eocene groundwater use in both the drinking and irrigation purposes in the study area.

The Eocene groundwater samples located in the three zones (fresh, brackish and saline zones). The fresh water type is due to the seepage from the irrigation canals (El-Ibrahimia and Bahr Yousf canals), while the brackish and saline water type is due to the carbonate materials that was transported from plateau of limestone by weathering as well as over-pumping activities and the leaching and dissolution processes for the marine deposits.

Also, the ionic ratios indicated that, the groundwater samples have a mixed mineralization that is possibly pure marine water affected by leaching, dissolution and cation exchange of both meteoric water and terrestrial salts. 
The hydrochemical facies and assemblages of hypothetical salts combinations indicated that; the groundwater of this aquifer is, chemically, goes through three stages of development; less chemically developed stage at the southern portion of the study area, intermediate state of development at the central portion of the study area and finally more chemically evoluted stage at the northern portion of the study area, as the groundwater is a mixture from the two aquifers due to the direct hydraulic connection between the Pleistocene aquifer and the Eocene fractured limestone aquifer through faulting. Also, this situation indicates that, the Eocene fractured limestone aquifer is recharged directly from the irrigation canals.

Both the assemblages of hypothetical salts combinations and Piper's trilinear diagram confirm that the Eocene aquifer is hydraulically connected with the overerlined Pleistocene aquifer through the faults plains. Also, the irrigation canals and the return flow after irrigation as well as the seepage from the upper aquifer (Pleistocene aquifer) are the main sources of recharging for the Eocene aquifer.

Most of the Eocene groundwater samples are under-saturated with aragonite and calcite, while all groundwater samples of the Eocene aquifer are under-saturated with respect to the halite, anhydrite and gypsum. This means that the Eocene groundwater in the study area can dissolve extra amounts of these mineral phases.

The groundwater samples of the Eocene aquifer in the study area are arranged with respect to the water quality for irrigation in the following sequence; $47 \%$ of the groundwater samples are good water, $20 \%$ of the groundwater samples are moderate water, $9 \%$ of the groundwater samples are intermediate water and $24 \%$ of the groundwater samples are bad water.

\section{Recommendation}

1- Land reclamation activities must be directed to the southern parts of the area as they have good water quality.

2- The modern irrigation system should be applied instead of the flood irrigation system to avoid the increase of water salinity through the return flow after irrigation processes in addition to the consumption of high quantity of groundwater.

3- Since the Eocene fractured limestone has good potentiality, exploitation of water should be focused on this aquifer, which directly increases the reclamation of new areas.

4- The coordination between the Ministry of Irrigation \& Water Resources and the Ministry of Agriculture and Land Reclamation should be taken into consideration to maximize the utilization of the extracted groundwater in the study area.

\section{References}

Abdel Moneim, A.A., J.P. Fernández-Álvarez, E.M. Abu El-Ella and A.M. Masoud, 2016. Groundwater management at west El-Minya desert area, Egypt using numerical molding. Journal of Geoscience and environmental protection, 4: 66-76.

Abu Heleika, M. and E. Niesner, 2009. Configuration of the limestone aquifers in the central part of Egypt using electrical measurements. Hydrogeology Journal, 17(2): 433-446.

Ahmed, A.A. and M.H. Ali, 2009. Hydrochemical evolution and variation of groundwater and its environmental impact at Sohag, Egypt. Arab Journal of Geosciences, 4(3-4): 339-352, Springer.

Appelo, C.A.J. and D. Postma, 2005. Geochemistry, Groundwater and Pollution, ${ }^{\text {nd }}$ Ed. CRC press Taylor and Francis group, Boca Raton, p: 668.

Back, W. and B.B. Hanshow, 1979. Major geochemical process in the evolution of carbonate aquifer system. Elsevier Scientific Publishing Company, Amesterdam -- Printed in the Netherlands. Journal of Hydrology, 43: 287-312.

Baena, C., B. Andreo, J. Mudry and F. Carrasco, 2008. Groundwater temperature and electrical conductivity as tools to characterize flow patterns in carbonate aquifers. The Sierra de las Nieves karts aquifer, southern Spain. Hydrogeology journal, Prof., 380-382.

Burdan, D.J., 1958. Metasomatism of groundwater at depth. UNESCO course on Hydrogeology, Desert Institute, Cairo.

Census estimation, 2019. Estimation of Central Agency for Public Mobilization and Statistics (in Arabic). 
Chebotarev, I.I., 1955. Metamorphism of natural water in the crust of weathering. Geochim. Cosmochim. Acta, 8: 22-48, 137-170, 198-212.

ElDeeb, H., M. El Rawy and E. Habib, 2015. Water resources management: case study of El-Minya governorate, Egypt. International Journal of Scientific \& Engineering Research, 6(6): 48-55.

Elewa, A.M.T., E. El-Sayed, M. El-Kashouty and M. Morsi, 2013. Quantitative study of surface and groundwater system in the western part of the River Nile, El-Minya Governorate, Upper Egypt: water quality in relation to anthropogenic activities. Greener Journal of Physical Sciences, 3(6): 212-228

El-Kashouty, M., 2010. Modeling of the limestone aquifer using isotopes, major, and trace elements in the western River Nile between Beni-Suef and El-Minya. Fourteenth International Water Technology Conference (IWTC14), Cairo, Egypt, 941- 968.

El-Kashouty, M., E. El-Sayed and A. Kamel, 2012. The hydrochemical characteristics and evolution of groundwater and surface water in the western part of the River Nile, El-Minya district, Upper Egypt. International conference "Transboundary Aquifers": Challenges and new directions" (ISARM), 1-7.

Fitzer, B., K. Heinrichs and D. Labouchardiers, 2002. Limestone weathering of historical monuments in Cairo, Egypt. Proceedings of the $5^{\text {th }}$ EC conference. Cultural heritage research; a panEuropean challenge, Cracow, Poland, p:367, ICSC-Institute of catalysis and surface chemistry/polish academy of science, Cracow/Poland, European communities.

Gates, J.B., W.M. Edmunds, J. Ma and B.R. Scanlom, 2008. Estimating groundwater recharge in a cold desert environment in northern China using chloride. Hydrogeology Journal, 16:893-910.

Hem, J.D., 1989. Study and interpretation of the chemical characteristics of natural water. U.S. Geol. Survey Water Supply, paper 2254, $3^{\text {rd }}$ edition, third printing, p: 272.

Ibrahim, R.G.M. and W.B. Lyons, 2017. Assessment of the hydrogeochemical processes affecting groundwater quality in the Eocene limestone aquifer at the desert fringes of El-Minya governorate, Egypt. Aquat geochem., 23: 33-52.

Ibrahim, S.M.M., 2013. Hydrological evaluation of the tertiary-quaternary aquifer system west Mallawi, Upper Egypt: case study. Egyptian Journal of Geology, 57: 1-30.

Ismail, E.R. Zaki and A. Kamel, 2015. Hydrochemistry and evaluation of groundwater suitability for irrigation and drinking purposes in west El-Minya district, North upper Egypt. Eighteenth International Water Technology Conference (IWTC18), 158-172.

IWACO and RIGW, 1986. Feasibility of vertical drainage in the Nile Valley, Minia pilot area. Ministry of irrigation, Cairo, Egypt.

Jacobson, R.L. and D. Langmuir, 1970. The chemical history of some spring waters in carbonate rocks. Ground Water 8 (3): 5-9.

Jankowski, J. and R.I. Acworth, 1997. Development of a contaminant plume from a municipal landfill: redox reaction and plume variability, In: J. Chilton, et al. (Eds.) Proceeding of the XXVII International Association of Hydrogeologist Congress on Groundwater in the Urban Environment, Nottingham, UK, Balkema, Rotterdam, 1: 439-444.

Korany, E., 1980. Peak runoff calculations and preventing the risk of occasional flooding in Sannur drainage basin, Eastern Desert, Beni Suef Governorate, Egypt. $5^{\text {th }}$ intern. Congr. Statist. Comput Sci, Cairo, 505-534.

Korany, E., S. Sakr, M. Darwish and S. Morsy, 2006. Hydrogeological modelling for the assessment of continuous rise of groundwater levels in the Quaternary aquifer, Nile Valley, Egypt: case study. Proceeding of the $8^{\text {th }}$ international conference on the geology of the Arab world (GAW8), Cairo University, 703-711.

Mckee, J.E. and H.W. Wolf, 1963. Water Quality Criteria. California State Water Quality Board Publication, 3A., U.S.A.

Meisler, H. and A.E. Becher, 1967. Hydrogeologic significance of calcium / magnesium ratios in groundwater from carbonate rocks in the Lancaster quadrangle, southeastern Pennsylvania. US. Geological survey, U.S.A., professional paper 575c, 232-235.

Pacheco, F.A.L. and T. Szocs, 2006. Dedolomitization Reactions driven by anthropogenic activity on lossy Sediments, SW Hungary. Appl. Geochem., 21:614-631.

Piper, A.M., 1953. A graphic representation in the geochemical interpretation of groundwater analysis. American Geophysical Union Transactions, U.S.A., 25: 914 - 923. 
Plummer, L.N., E.C. Prestemon and D.L. Parkhurst, 1994. An interactive code (NETPATH) for modeling NET geochemical reactions along a flow PATH. Version 2.0. Water-Resources Investigations Report 94-4169. Reston, Virginia: U.S. Geological Survey.

Rainwater, F.H. and L.L. Thatcher, 1960. Methods for collection and analysis of water samples. U.S. Geol. Surv. Water Supply. Paper No.1454, U.S.A., p: 301.

Ravbar, N. and N. Goldscheider, 2009. Comparative application of four methods of groundwater vulnerability mapping in a Solvene karst catchment. Hydrogeology journal, 17(3): 725-733

Said, R., 1997. The geological evolution of the River Nile. Springer-Verlag.

Salem, A.A.A., 2015. Hydrogeological studies on the shallow aquifer in the area west Samalot, ElMinya governorate, Egypt. Egyptian Journal of Pure and Applied Science, 53(4): 49-60.

Shabana, A.R., 2010. Hydrogeological studies on the area west Deir Mouas-Mallawi, El-Minya governorate, Egypt. Egyptian journal of geology, 54: 61-78.

Starinsky, A., M. Bielski, A. Ecker and G. Steinitz, 1983. Tracing the origin of salts in groundwater by $\mathrm{Sr}$ isotopic composition (the crystalline complex of the southern Sinai), Egypt. Isotope Geoscience, 1: 257-267.

Tantawy, M.A., 1992. Isotopic and hydrochemical application to the surface and groundwater assessments in El-Minya district, Egypt. Ph.D. thesis, fac. of Sci., El-Minya Univ., Egypt.

Tantawy, M., E. El Sayed, I. Setto and E. Abu El Seba, 2006. Hydrochemical evaluation of the groundwater resources in the area east of El Minya district, Egypt. El-Minya Science Bulletin, Fac. of Sci., El Minya University, 17(1): 24-57.

Tihansky, B. and L.A. Knochenmus, 2001. Karst features and hydrogeology in west-central FloridaA field perspective. US Geol. Survey Water-Resources Investigation Report 01-4011: 198-211.

U.S. Salinity Laboratory Staff, 1954. Diagonsis and improvement saline and alkali soil: Agric, handbook, 60, Washington, D.C., 1-60.

Vega, M., R. Pardo, E. Barrado and L. Deban, 1998. Assessment of seasonal and polluting effects on the quality of river water by exploratory data analysis. Water Research 32: 3581-3592.

World Health Organization (WHO, 2011). The guidelines for drinking water quality, $4^{\text {th }}$ ed.

Yang, Q., H. Xiao, L. Zhoa, Y. Yang, C. Li, and L. Yin, 2011. Hydrological and isotopic characterization of river water, groundwater, and groundwater recharge in the Heihe River basin, northwestern China hydrological processes, 25: $1271-1283$.

Youssef, M.I., 1968. Structural pattern of Egypt and its interpretation. AAPG. Bull., 52: 601-614.

Yousif, M., H. Sabet, S. Ghoubachi and A. Aziz, 2018. Utilizing the geological data and remote sensing applications for investigation of groundwater occurrences, West El Minia, Western Desert of Egypt, NRIAG Journal of Astronomy and Geophysics, 7 (2): 318-333.

Zhu, G.F., Z.Z. Li, Y.H. Su, J.Z. Ma, and Y.Y. Zhang, 2007. Hydrogeochemical and isotope evidence of groundwater evolution and recharge in Minqin Basin, northwest China. Journal of hydrology, 333: $239-251$. 